\title{
Allosteric Spin Crossover Induced by Ligand-Based Molecular Alloying
}

\author{
Carlos Bartual-Murgui, ${ }^{*}$ Cristian Pérez-Padilla, Simon J. Teat, Olivier Roubeau,* and Guillem Aromí*
}

Cite This: https://dx.doi.org/10.1021/acs.inorgchem.0c01061

Read Online

ACCESS

Llll Metrics \& More

Article Recommendations

Supporting Information

ABSTRACT: The spin crossover (SCO) phenomenon represents a source of multistability at the molecular level, and dilution into a nonactive host was originally key to understand its cooperative nature and the parameters governing it in the solid state. Here, we devise a molecular alloying approach in which all components are SCO-active, but with significantly different characteristic temperatures. Thus, the molecular material $\left[\mathrm{Fe}(\mathrm{Mebpp})_{2}\right]\left(\mathrm{ClO}_{4}\right)_{2}(2)$ has been doped with increasing amounts of the ligand Me2bpp (Mebpp and Me2bpp = methyl- and bis-methyl-substituted bis-pyrazolylpyridine ligands), yielding molecular alloys with the formula [Fe$\left.(\mathrm{Mebpp})_{2-2 x}(\mathrm{Me} 2 \mathrm{bpp})_{2 x}\right]\left(\mathrm{ClO}_{4}\right)_{2}(4 x ; 0.05<x<0.5)$. The effect of the composition on the SCO process is studied through singlecrystal X-ray diffraction (SCXRD), magnetometry, and differential

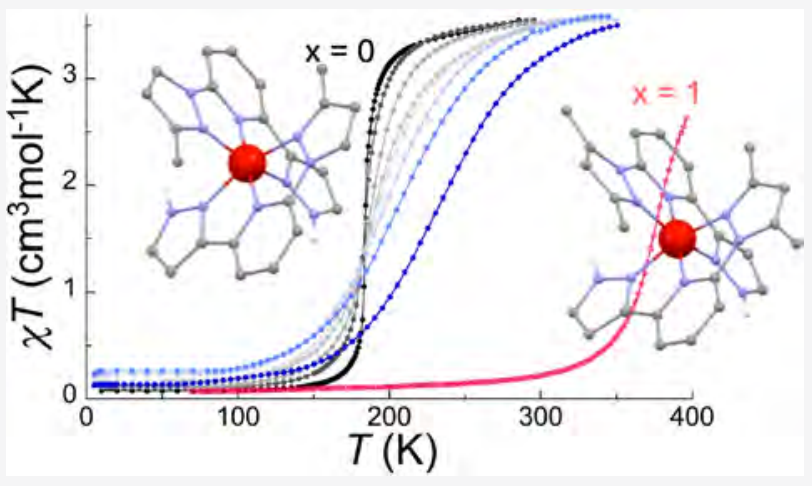
scanning calorimetry (DSC). While the attenuation of intermolecular interactions is shown to have a strong effect on the SCO cooperativity, the spin conversion was found to occur at intermediate temperatures and in one sole step for all components of the alloys, thus unveiling an unprecedented allosteric SCO process. This effect provides in turn a means of tuning the SCO temperature within a range of $42 \mathrm{~K}$.

$S^{\text {p }}$ pin crossover compounds are a very intensely studied family of molecular materials. ${ }^{1-4}$ They are made of transition metals able to display two different distributions with similar energy of their d electrons and thus to lie easily in two distinct spin states (low and high spin; LS and HS, respectively). Therefore, one can shuttle reversibly between them by employing external stimuli (light, heat, pressure, or chemical environment changes etc.). Since both states exhibit different magnetic as well as other physical properties, SCO systems are very promising as potential molecular switches for the construction of nanoscopic functional devices. 5,6 One major goal is therefore to gain control over their key features, such as the switching temperature. In this context, $\mathrm{Fe}$ (II) is the most exploited ion, ${ }^{7-9}$ since it can toggle between a nonmagnetic (LS; $S=0$ ) and a magnetic (HS; $S=2$ ) state, undergoing significant changes in optical, dielectric, structural, and other properties. The structural changes result from differences of around $10 \%$ in $\mathrm{Fe}-\mathrm{L}$ ( $\mathrm{L}=$ ligand donor atom) distances between both states. These are at the root of important structural effects associated with the spin-state switching, ${ }^{10}$ such as crystallographic phase transitions ${ }^{11}$ or symmetry breaking. ${ }^{12-14}$ Also, the propagation of these changes through the crystal lattice by elastic interactions is at the origin of cooperativity, ${ }^{15}$ which is the essential requirement to observe bistability. ${ }^{16}$ The latter is another key feature of potential switchable functional materials; therefore, important efforts have been devoted to establish precise relationships between structure and cooperativity with a view of predicting or mastering its effects. ${ }^{17}$ Attempts to assess the effect of intermolecular interactions on cooperativity involve the investigation of families of SCO compounds by systematically varying some lattice component, such as counterions ${ }^{18-22}$ or solvent molecules of crystallization. ${ }^{23-31}$ Series of analogous complexes with systematic changes in the periphery of the ligands have been studied as well. ${ }^{30,32-36}$ Another approach targets the preparation of various polymorphs of SCO compounds, ${ }^{11,37-40}$ thus keeping the exact same composition while changing the crystallographic arrangement of the components. Differences in the spin-switching properties originate in these cases exclusively from the crystal lattice. All the above studies base their conclusions on the effect of replacing one entire crystallographic lattice by another. There is a more subtle procedure, consisting of gradually replacing one component from the crystal network and observing the effect of this progressive substitution on the temperature, completeness, and abruptness of the SCO. ${ }^{41,42}$ This method

Received: April 13, 2020 
allows one to focus on specific aspects defining the cooperativity as well as the temperature of the transition. Most efforts have focused on doping the crystal lattice of $\mathrm{Fe}$ (II) SCO complexes with isostructural species of nonswitching $\mathrm{M}(\mathrm{II})$ metals ( $\mathrm{Zn}, \mathrm{Ni}, \mathrm{Mn}, \mathrm{Co}$, or $\mathrm{Cd}$ ). Here, the insertion of species that do not undergo a spin transition interrupts the propagation of the structural changes of the SCO, thus diminishing the cooperativity. ${ }^{43-51}$ This metal dilution also affects the amount of residual HS or LS species at the lower or higher temperature regions, respectively. More specifically, using metals with $r\left(\mathrm{M}^{2+}\right)>r\left(\mathrm{Fe}^{2+}\right)$ stabilizes the HS state, whereas metals with $r\left(\mathrm{M}^{2+}\right)<r\left(\mathrm{Fe}^{2+}\right)$ favors the LS state of $\mathrm{Fe}^{2+}$, as a result of a "negative" and "positive" chemical pressure, respectively. ${ }^{52,53}$ The SCO temperature suffers a decrease upon dilution as well, ${ }^{47,48,54-67}$ which has been modeled by quantifying the change in HS to LS free energy differences caused by the changes in elastic interactions within the lattice with the varying compositions. A very special case of this type of doping consists of incorporating structurally related complexes featuring both a different metal and different ligands but sufficiently close structurally to the host species to form solid solutions with it. In such cases, the influence of the SCO of the host on the properties of the guest is studied. ${ }^{66,68-70}$ The doping approach, also termed molecular alloying, has been used only very rarely when the variable component is solely a ligand of the SCO complex rather than the metal or both. This variation affects the intermolecular interactions within the lattice while not diminishing the number of potential SCO centers. Therefore, the variable of internal pressure is expected to play a role in the analysis here different from that with the mixed-metal systems. A pioneering achievement was that of reducing the temperature of the wide hysteresis of the $1 \mathrm{D}$ polymeric compound $\left[\mathrm{Fe}(\mathrm{Htrz})_{3}\right]\left(\mathrm{ClO}_{4}\right)_{2}(\mathrm{Htrz}=1,2,4-$ triazole; $\Delta T=17 \mathrm{~K}$, centered at $304.5 \mathrm{~K})$ to convenient values by ligand-based molecular alloying. The ligand 4-amino1,2,4-triazole (4- $\left.\mathrm{NH}_{2} \mathrm{trz}\right)$, similar to that of the original material, was introduced randomly into the parent system, thus generating solid solutions of coordination chains with composition $\left[\mathrm{Fe}(\mathrm{Htrz})_{3-3 x}\left(4-\mathrm{NH}_{2} \mathrm{trz}\right)_{3 x}\right]\left(\mathrm{ClO}_{4}\right)_{2}{ }^{71}$ Since the other pure polymer $\left[\mathrm{Fe}\left(4-\mathrm{NH}_{2} \mathrm{trz}\right)_{3}\right]\left(\mathrm{ClO}_{4}\right)_{2}$ undergoes a gradual SCO at $130 \mathrm{~K}$, it was found that ligand-based alloys in the $0<x<0.1$ range exhibit hysteresis loops centered at the temperatures given by $T(x)=304.5-170 x$. The doping of the ligand also causes a reduction in the hysteresis width $(\Delta T(x)=$ $17-20 x \mathrm{~K})$. This system was later analyzed for all possible compositions $(0<x<1)$, which allowed refinement of the numerical dependences with $x$, while a thermodynamic model was proposed on the basis of the existence of alloys made of mixtures of two different $1 \mathrm{D}$ chains. $^{72}$ More recently, an analogous study was performed on the coordination polymer $\left[\mathrm{Fe}(\text { btzx })_{3}\right]\left(\mathrm{ClO}_{4}\right)_{2} \quad($ btzx $=1,4$-bis(tetrazol-1-yl)-p-xylene $)$, with the progressive substitution of btzx by the structurally related ligand 1,4-bis(triazol-1-yl)-p-xylene (btix). ${ }^{73}$ This produced mixtures of the alloy $\left[\mathrm{Fe}(\text { btzx })_{3-3 x}(\text { btix })_{3 x}\right]\left(\mathrm{ClO}_{4}\right)_{2}$ that was more accurately described as chains with a statistical and random distribution of both bridging ligands for each composition (as given by $x$ ). The solid solutions exhibit a magnetic behavior different from that of both pure compounds, with the appearance of additional SCO events. The alloy is maintained only until $x \approx 0.5$. Beyond this composition, the separation of the pure phase $\left[\mathrm{Fe}(\mathrm{btix})_{3}\right]$ $\left(\mathrm{ClO}_{4}\right)_{2}$ is observed. To the best of our knowledge, ligandonly-based molecular alloying on discrete SCO complexes has not yet been performed. This could provide an opportunity of tuning the switching temperature of valuable SCO molecular systems while not diminishing the number of active centers. We recently reported a method to obtain two polymorphs of the molecular SCO material $\left[\mathrm{Fe}(\mathrm{bpp})_{2}\right]\left(\mathrm{ClO}_{4}\right)_{2}(\mathbf{1} ; \mathrm{bpp}=2$ (pyrazol-1-yl)-6-(pyrazol-3-yl)pyridine). ${ }^{37}$ These two polymorphs, $1 \alpha$ and $\mathbf{1} \beta$, crystallize in two different space groups $\left(P 2_{1} / c\right.$ and $P 2_{1} / n$, respectively) and exhibit an abrupt SCO with a very narrow hysteresis, centered at 277 and $315 \mathrm{~K}$, respectively, with quite different cooperativities. In addition, we prepared the derivatives $\left[\mathrm{Fe}(\mathrm{Mebpp})_{2}\right]\left(\mathrm{ClO}_{4}\right)_{2}(2)$ and $\left[\mathrm{Fe}(\mathrm{Me} 2 \mathrm{bpp})_{2}\right]\left(\mathrm{ClO}_{4}\right)_{2}$ (3) using the methyl-functionalized ligands (Scheme 1) 2-(3-methylpyrazol-1-yl)-6-(pyrazol-3yl)pyridine (Mebpp) and 2-(3,5-dimethylpyrazol-1-yl)-6-(pyrazol-3-yl)pyridine (Me2bpp). ${ }^{74}$ Interestingly, these complexes (Figure 1) are arranged in the crystal lattice as polymorphs $1 \alpha$ and $\mathbf{1} \beta$, respectively (Figure $\mathrm{S} 1$ ).

Scheme 1. Ligands Mebpp and Me2bpp
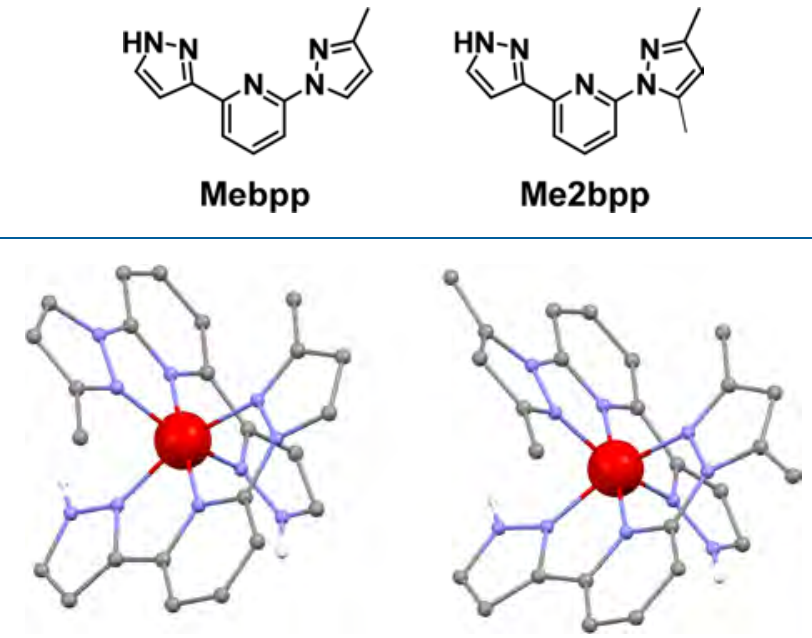

Figure 1. Representation of the molecular structure of the complex cations of $\left[\mathrm{Fe}(\mathrm{Mebpp})_{2}\right]\left(\mathrm{ClO}_{4}\right)_{2} \quad$ (2, left) and $\left[\mathrm{Fe}(\mathrm{Me} 2 \mathrm{bpp})_{2}\right]-$ $\left(\mathrm{ClO}_{4}\right)_{2}$ (3, right). Color code: red, $\mathrm{Fe}$; gray, $\mathrm{C}$; purple, $\mathrm{N}$; white, $\mathrm{H}$. Only hydrogen atoms from $\mathrm{N}-\mathrm{H}$ moieties are shown.

The magnetic properties of $\mathbf{2}$ and $\mathbf{3}$ are certainly influenced by the crystal packing but are strongly affected by the presence of methyl groups at positions 5 and/or 3 of the pyrazol-1-yl ring for steric reasons. They thus exhibit an abrupt SCO at $T_{\text {SCO }}=184$ and $378 \mathrm{~K}$, respectively. ${ }^{74}$ In this work, we take advantage of the structural similarity between the complexes of 2 and $\mathbf{3}$ and yet their very different SCO properties, to undertake a study of molecular alloying by introducing gradually increased fractions of the ligand Me2bpp to the reaction conducing to complex 2 , thus producing solid solutions of the composition [Fe(Mebpp $\left.)_{2-2 x}(\mathrm{Me} 2 \mathrm{bpp})_{2 x}\right]$ $\left(\mathrm{ClO}_{4}\right)_{2}(4 x ; 0.05<x<0.5)$. All of these alloys contain three molecular components in varying and statistical amounts: 2, 3, and their heteroleptic derivative $[\mathrm{Fe}(\mathrm{Mebpp})(\mathrm{Me} 2 \mathrm{bpp})]$ $\left(\mathrm{ClO}_{4}\right)_{2}$. The influence of this dilution on the SCO temperature and the cooperativity is analyzed via extensive single-crystal X-ray diffraction (SCXRD), as well as mass spectrometry (MS), magnetic susceptibility measurements, and differential scanning calorimetry (DSC). At all dilutions, the $\mathrm{SCO}$ is found to be complete in one sole conversion for all 
components, thus unveiling an allosteric effect, opening up a convenient method to tune the SCO temperature.

\section{EXPERIMENTAL SECTION}

Synthesis. The ligands 2-(3-methylpyrazol-1-yl)-6-(pyrazol-3-yl)pyridine (Mebpp) and 2-(3,5-dimethylpyrazol-1-yl)-6-(pyrazol-3-yl)pyridine (Me2bpp), as well as the complexes $\left[\mathrm{Fe}(\mathrm{Mebpp})_{2}\right]\left(\mathrm{ClO}_{4}\right)_{2}$ (2) and $\left[\mathrm{Fe}(\mathrm{Me} 2 \mathrm{bpp})_{2}\right]\left(\mathrm{ClO}_{4}\right)_{2}$ (3), were prepared as previously reported. ${ }^{74}$ Caution! Perchlorate salts of metal complexes are potentially explosive. Only small quantities of material should be prepared, and the samples should be handled with care.

$\left[\mathrm{Fe}(\mathrm{Mebpp})_{2-2 x}(\mathrm{Me} 2 \mathrm{bpp})_{2 x}\right]\left(\mathrm{ClO}_{4}\right)_{2}(4 x ; 0.05<x<0.5)$. To solutions of $\mathrm{Fe}\left(\mathrm{ClO}_{4}\right)_{2} \cdot 6 \mathrm{H}_{2} \mathrm{O}(0.023 \mathrm{~g}, 0.065 \mathrm{mmol})$ and ascorbic acid $(\sim 2 \mathrm{mg})$ in absolute ethanol $(10 \mathrm{~mL})$ were added dropwise solutions of Mebpp $(0.027(1-x) \mathrm{g}, 0.12(1-x) \mathrm{mmol})$ and Me2bpp $(0.029 x \mathrm{~g}, 0.12 x \mathrm{mmol})$ in absolute ethanol $(10 \mathrm{~mL})$. The resulting dark yellow solutions were stirred for $40 \mathrm{~min}$ at room temperature. The solutions were then filtered and layered with $\mathrm{Et}_{2} \mathrm{O}(1 / 1 \mathrm{v} / \mathrm{v})$. Yellow crystals of the products suitable for single-crystal X-ray diffraction were obtained as homogeneous phases, after approximately 4 days. Typical yields: $\sim 40 \%$. Anal. Calcd (found) for $\mathrm{Fe}-$ $\left(\mathrm{C}_{12} \mathrm{H}_{11} \mathrm{~N}_{5}\right)_{1.9}\left(\mathrm{C}_{13} \mathrm{H}_{13} \mathrm{~N}_{5}\right)_{0.1}\left(\mathrm{ClO}_{4}\right)_{2}(x=0.05)$ : C, 41.00 (40.60); $\mathrm{H}, 3.17$ (3.14); N, 19.85 (19.41). Calcd (found) for $\mathrm{Fe}-$ $\left(\mathrm{C}_{12} \mathrm{H}_{11} \mathrm{~N}_{5}\right)_{1.8}\left(\mathrm{C}_{13} \mathrm{H}_{13} \mathrm{~N}_{5}\right)_{0.2}\left(\mathrm{ClO}_{4}\right)_{2}(x=0.1): \mathrm{C}, 41.08(40.96) ; \mathrm{H}$, 3.19 (3.14); N, 19.81 (19.48). Calcd (found) for $\mathrm{Fe}-$ $\left(\mathrm{C}_{12} \mathrm{H}_{11} \mathrm{~N}_{5}\right)_{1.6}\left(\mathrm{C}_{13} \mathrm{H}_{13} \mathrm{~N}_{5}\right)_{0.4}\left(\mathrm{ClO}_{4}\right)_{2}(x=0.2): \mathrm{C}, 41.26(40.59) ; \mathrm{H}$, 3.24 (3.21); N, 19.73 (19.14). Calcd (found) for $\mathrm{Fe}-$ $\left(\mathrm{C}_{12} \mathrm{H}_{11} \mathrm{~N}_{5}\right)_{1.4}\left(\mathrm{C}_{13} \mathrm{H}_{13} \mathrm{~N}_{5}\right)_{0.6}\left(\mathrm{ClO}_{4}\right)_{2}(x=0.3): \mathrm{C}, 41.46(40.99) ; \mathrm{H}$, 3.25 (3.21); N, 19.63 (19.44). Calcd (found) for $\mathrm{Fe}-$ $\left(\mathrm{C}_{12} \mathrm{H}_{11} \mathrm{~N}_{5}\right)_{1.2}\left(\mathrm{C}_{13} \mathrm{H}_{13} \mathrm{~N}_{5}\right)_{0.8}\left(\mathrm{ClO}_{4}\right)_{2}(x=0.4): \mathrm{C}, 41.61(41.45) ; \mathrm{H}$, 3.32 (3.34); N, 19.58 (19.07). Calcd (found) for $\mathrm{Fe}-$ $\left(\mathrm{C}_{12} \mathrm{H}_{11} \mathrm{~N}_{5}\right)_{1.0}\left(\mathrm{C}_{13} \mathrm{H}_{13} \mathrm{~N}_{5}\right)_{1.0}\left(\mathrm{ClO}_{4}\right)_{2}(x=0.5): \mathrm{C}, 41.75(41.29) ; \mathrm{H}$, 3.36 (3.30); N, 19.47 (19.27). ESI MS: $m / z 505.2$ ([Fe(Mebpp) $\left.{ }_{2}\right]-$ $\left.\left[\mathrm{H}^{+}\right]\right)^{+}, 519.2\left([\mathrm{Fe}(\mathrm{Mebpp})(\mathrm{Me} 2 \mathrm{bpp})]-\left[\mathrm{H}^{+}\right]\right)^{+}, 533.2([\mathrm{Fe}-$ $\left.\left.(\mathrm{Me} 2 \mathrm{bpp})_{2}\right]-\left[\mathrm{H}^{+}\right]\right)^{+}, 605.11\left(\left[\mathrm{Fe}(\mathrm{Mebpp})_{2}\right]\left(\mathrm{ClO}_{4}\right)-2\left[\mathrm{H}^{+}\right]\right)^{+}$, $619.13\left([\mathrm{Fe}(\mathrm{Mebpp})(\mathrm{Me} 2 \mathrm{bpp})]\left(\mathrm{ClO}_{4}\right)-2\left[\mathrm{H}^{+}\right]\right)^{+}, 633.14([\mathrm{Fe}-$ $\left.(\mathrm{Me} 2 \mathrm{bpp})]\left(\mathrm{ClO}_{4}\right)-2\left[\mathrm{H}^{+}\right]\right)^{+}$.

Characterization. Elemental analysis was performed with an elemental microanalyzer (A5), Model Flash 1112, at the Servei de Microanalisi of the CSIC, Barcelona, Spain. IR spectra were recorded on $\mathrm{KBr}$ pellet samples on a Nicolet AVATAR 330 FTIR spectrometer. MALDI-TOF mass spectrometry measurements were performed on a 400 ABSciex MALDI-TOF spectrometer at the Unitat d'Espectrometria de Masses de Caracterització Molecular (CCiT) of the University of Barcelona. Samples were prepared as follows: $5 \mu \mathrm{L}$ of the solution was diluted in $5 \mathrm{~mL}$ of $\mathrm{MeOH}$. Then, $0.5 \mu \mathrm{L}$ of an internal reference solution, containing $10 \mathrm{mg} / \mathrm{mL}$ of DCTB in dichloromethane, was added before injection. Powder X-ray diffraction patterns were obtained at RT using a D-Max Rigaku Ru300 diffractometer equipped with a $\mathrm{Cu}$ rotating anode and graphite monochromator to select the $\mathrm{Cu} \mathrm{K} \alpha$ wavelength, through the Servicio General de Apoyo a la Investigación-Universidad de Zaragoza.

Single-Crystal X-ray Diffraction (SCXRD). Data for the series $4 x$ were acquired on a Bruker APEX II QUAZAR diffractometer equipped with a microfocus multilayer monochromator with Mo $\mathrm{K} \alpha$ radiation $(\lambda=0.71073 \AA)$ at $100 \mathrm{~K}$, except for $x=0.15$, for which data were obtained on a Bruker APEX II CCD diffractometer at the Advanced Light Source beamline 11.3.1 at Lawrence Berkeley National Laboratory, from a silicon 111 monochromator $(\lambda=$ $0.77490 \AA$ ) at 100 and $280 \mathrm{~K}$. The temperature dependence of the cell parameters was obtained on the same setups. Data reduction and absorption corrections were performed with respectively SAINT and SADABS. ${ }^{75}$ All structures were solved by intrinsic phasing with SHELXT $^{76}$ and refined by full-matrix least squares on $F^{2}$ with SHELXL-2014. ${ }^{77}$ Except for $x=0.4$ and 0.5 , the partial methyl groups of the structure have been refined isotropically. Refinement of the two partial methyl groups was first done with free occupancy but the same $U_{\text {iso }} / U_{\text {eq }}$ so as to evaluate the relative occupancies of both sites. In all cases, the sum of the occupancies was close to the value of $x$ used in the reagent mixture (for $x=0.05$, this was forced, as the electron density was too weak to allow a free refinement). Then only were the occupancies fixed at the closest "regular" decimal value, with the sum of both occupancies fixed at the value used in the reagent mixture. All details can be found in CCDC 1993012-1993019, which contain the supplementary crystallographic data for this paper. These data can be obtained free of charge from The Cambridge Crystallographic Data Center via https://summary.ccdc.cam.ac.uk/structure-summary-form. Crystallographic and refinement parameters are summarized in Tables $\mathrm{S} 1$ and $\mathrm{S} 2$ together with average $\mathrm{Fe}-\mathrm{N}$ bond lengths. Selected bond lengths and angles and intermolecular distances are given in Table S3 and Table 2.

Magnetic Measurements. Magnetic measurements were performed with either a MPMS5 or MPMS-XL SQUID magnetometer, respectively, through the "Unitat de mesures Magnètiques" of the Universitat de Barcelona or the "Servicio General de Apoyo a la Investigación-SAI”, Universidad de Zaragoza. The applied magnetic field was either 0.5 or $1 \mathrm{~T}$. Corrections of the diamagnetic contributions of the sample holder and the sample were applied. Samples were in all cases crystals used as obtained from the synthesis as a homogeneous phase, gently crushed within the gelatin capsule sample holder. Measurements were done in settle mode: i.e., the temperature was stabilized before measurement at each temperature, with an additional $10 \mathrm{~s}$ wait to ensure thermalization. The temperature was varied at $10 \mathrm{~K} / \mathrm{min}$ between each temperature set point, resulting in an overall average ca. $0.8 \mathrm{~K} / \mathrm{min}$ scan rate.

Differential Scanning Calorimetry. Differential scanning calorimetry (DSC) was carried out at a scan rate of $10 \mathrm{~K} \mathrm{~min}^{-1}$ with a Q1000 calorimeter from TA Instruments equipped with an LNCS accessory. The temperature and enthalpy scales were calibrated with the melting transition of a standard sample of In $\left(156.6^{\circ} \mathrm{C}, 3296\right.$ $\left.\mathrm{J} \mathrm{mol}{ }^{-1}\right)$. Samples were the same as those used for magnetic measurements: i.e., gently crushed crystals, as obtained from the synthesis as homogeneous phases. Mechanically crimped $\mathrm{Al}$ pans with an empty pan as a reference were used. A synthetic sapphire was measured in the same temperature range to derive heat capacity. By comparison, an overall accuracy of $0.2 \mathrm{~K}$ for the temperature and up to $10 \%$ for the heat capacity was estimated. The excess heat capacity associated with the SCO process was derived by estimating a lattice heat capacity from the data above and below the SCO anomaly. The excess enthalpy and entropy associated with the SCO, $\Delta_{\mathrm{SCO}} H$ and $\Delta_{\mathrm{SCO}} S$, respectively, were determined by integration of the excess heat capacity (shown in Figure 5) over $T$ and $\ln T$, respectively.

\section{RESULTS AND DISCUSSION}

Synthesis and Mass Spectrometry. The series of compounds $\left[\mathrm{Fe}(\mathrm{Mebpp})_{2-2 x}(\mathrm{Me} 2 \mathrm{bpp})_{2 x}\right]\left(\mathrm{ClO}_{4}\right)_{2} \quad(4 x ; 0.05$ $<x<0.5)$ was prepared through reactions in ethanol of $\mathrm{Fe}\left(\mathrm{ClO}_{4}\right)_{2} \cdot 6 \mathrm{H}_{2} \mathrm{O}$ with Mebpp/ $\mathrm{Me}_{2} \mathrm{bpp}$ mixtures of the appropriate composition, followed by the layering of the resulting solutions in $\mathrm{Et}_{2} \mathrm{O}$, in the same manner as reported for 2 and $3{ }^{74}$ Homogeneous phases of good-quality single crystals were obtained for the compositions with $x=0.05,0.1,0.15$, $0.2,0.3,0.4,0.5$. All characterization techniques indicate that the compositions of the crystals are extremely similar to those of the reagent mixtures, so that we have opted to use these values of $x$ throughout this work, as they cannot be easily determined with more accuracy. For compositions with $x>$ 0.5 , it was not possible to obtain single phases. Instead, crystals of 3 and of molecular alloys of the $4 x$ type (vide infra) were obtained. This clearly indicates that systems with $x>0.5$ cannot be accommodated as solid solutions in the crystal lattice of $1 \alpha$ (that of compounds $4 x$, for $0.05<x<0.5$, and of 2, where $x=0$; Figure S1).

The reaction mixtures were analyzed after $30 \mathrm{~min}$ of stirring by mass spectrometry. The crystals later isolated from all these systems were dissolved and analyzed as well. All of the spectra 


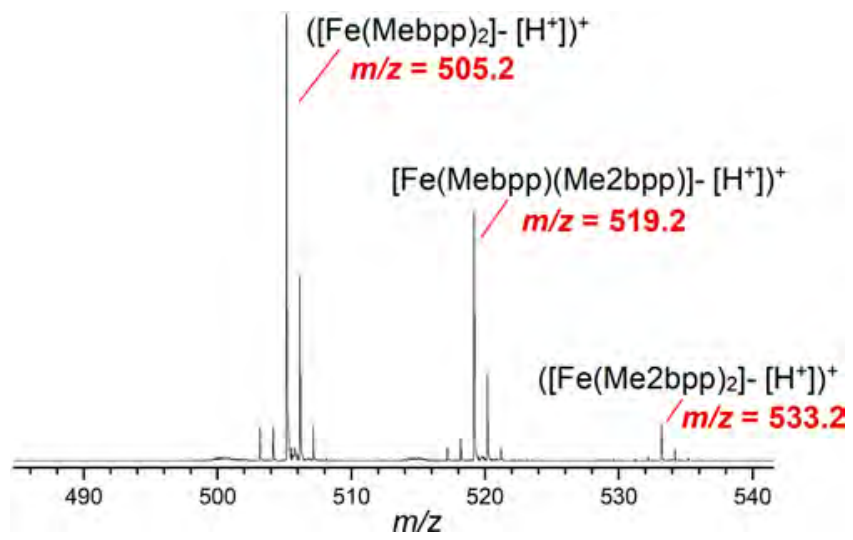

Figure 2. Representative ESI-MS spectrogram of crystals of complexes $\left[\mathrm{Fe}(\mathrm{Mebpp})_{2-2 x}(\mathrm{Me} 2 \mathrm{bpp})_{2 x}\right]\left(\mathrm{ClO}_{4}\right)_{2}(4 x ; 0.05<x<$ 0.5 , here $x=0.2$ ) dissolved in $\mathrm{MeOH}$, showing fragments of the three possible complexes present: $\left[\mathrm{Fe}(\mathrm{Mebpp})_{2}\right]^{2+},[\mathrm{Fe}(\mathrm{Mebpp})-$ $(\mathrm{Me} 2 \mathrm{bpp})]^{2+}$, and $\left[\mathrm{Fe}(\mathrm{Me} 2 \mathrm{bpp})_{2}\right]^{2+}$.

exhibit three prominent peaks corresponding to the three possible fragments of $\mathrm{Fe}(\mathrm{II})$ coordinated to two bpp ligands (Figure 2): namely, $\left(\left[\mathrm{Fe}(\mathrm{Mebpp})_{2}\right]-\left[\mathrm{H}^{+}\right]\right)^{+}(\mathrm{m} / z$ 505.2), $\left([\mathrm{Fe}(\mathrm{Mebpp})(\mathrm{Me} 2 \mathrm{bpp})]-\left[\mathrm{H}^{+}\right]\right)^{+}(\mathrm{m} / z$ 519.2), and $[\mathrm{Fe}-$ $\left.\left.(\mathrm{Me} 2 \mathrm{bpp})_{2}\right]-\left[\mathrm{H}^{+}\right]\right)^{+}(\mathrm{m} / z$ 533.2). While the relative intensity of the heteroleptic species increases as $x$ approaches 0.5 , the presence of the three fragments in all the diagrams suggests that the former is not specially favored and the distribution of ligands among the complex cations may be close to statistical. In each case, the composition is maintained upon crystallization, since the results from the initial solutions are almost the same as those from the dissolved single crystals for almost all of the compositions studied (Figure S2).

Single-Crystal X-ray Diffraction. SCXRD data were collected on single crystals of $\left[\mathrm{Fe}(\mathrm{Mebpp})_{2-2 x}(\mathrm{Me} 2 \mathrm{bpp})_{2 x}\right]$ $\left(\mathrm{ClO}_{4}\right)_{2}(4 x)$ with several compositions $(x=0.05,0.1,0.15$, $0.2,0.3,0.4,0.5)$ at $100 \mathrm{~K}$. All compounds crystallize in the monoclinic space group $C 2 / c$, the same as that for complex 2 . The composition revealed by the refined models of these data is indeed consistent with solid solutions as formulated for $4 x$. Thus, in all cases, the asymmetric unit (Figure 3 ) is solventfree and is composed of one $\left[\mathrm{Fe}(\mathrm{Mebpp})_{2-2 x}(\mathrm{Me} 2 \mathrm{bpp})_{2 x}\right]^{2+}$ cation (which corresponds to the average species of the

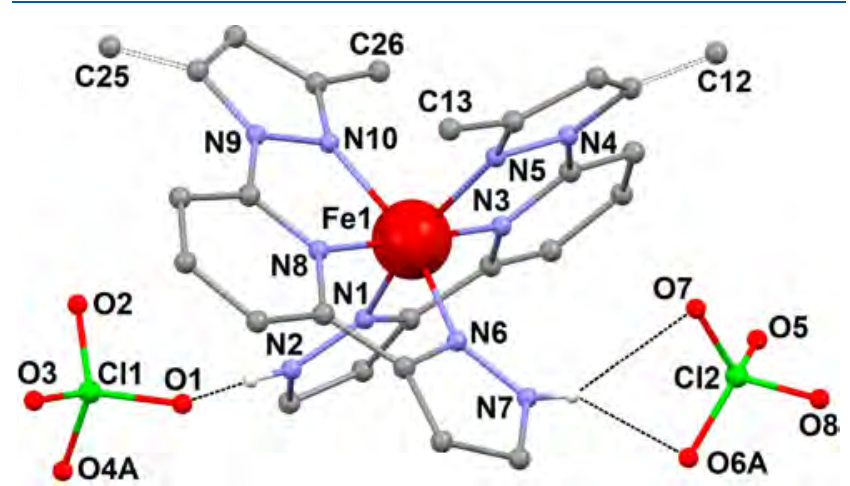

Figure 3. Representation of a molecular structure representative of the molecular alloys $\left[\mathrm{Fe}(\mathrm{Mebpp})_{2-2 x}(\mathrm{Me} 2 \mathrm{bpp})_{2 x}\right]\left(\mathrm{ClO}_{4}\right)_{2}(4 x)$, here for $x=0.5(T=100 \mathrm{~K})$. The $\mathrm{C}$ atoms of the partially occupied methyl groups of Me2bpp (C12 and C25) are shown linked to the pyrazolyl ring with dashed bonds. Black dashed lines are hydrogen bonds. Only hydrogen atoms from $\mathrm{N}-\mathrm{H}$ moieties are shown. statistical solid solution) in addition to two $\mathrm{ClO}_{4}{ }^{2-}$ anions to ensure electroneutrality. The anions form hydrogen bonds to the $\mathrm{N}-\mathrm{H}$ groups of the complex cation. This cation features an $\mathrm{Fe}$ (II) center chelated by two approximately perpendicular tridentate bpp ligands, yielding a distorted-octahedral geometry. The identity of each of these ligands is Mebpp or Me2bpp, distributed randomly among all the complexes of the lattice in the proportion given by $x$. The distributions at both ligand positions can be distinguished on the basis of residual electron density at the corresponding atom sites and are not necessarily identical. The specific composition reported at each ligand position (Table 1) reflects on the occupancies of the 5methyl substituent of Me2bpp (C25 and C12) that optimize their displacement parameters, the ensemble satisfying the composition given by $x$.

The presence of the partially occupied 5-methyl substituents into the alloy engenders disorder to the $\mathrm{ClO}_{4}{ }^{-}$anions, which becomes more apparent for $x=0.1$ or larger. Slightly different chemical environments at both sites originate the occupation disparities between $\mathrm{C} 12$ and $\mathrm{C} 25$. The average $\mathrm{Fe}-\mathrm{N}$ distances across the series span the 1.962-1.966 $\AA$ range, indicating that the metal centers lie in the LS state at $100 \mathrm{~K}$. The molecular structure was also determined at $280 \mathrm{~K}$ for $x=0.15$ (Table S2). The essential features of the structure at higher temperature are similar to those described above for the systems measured at $100 \mathrm{~K}$. The most significant quantitative change is an increase in the $\mathrm{Fe}-\mathrm{N}$ bond distances by approximately $8 \%$, amounting to $2.15(2) \AA$ on average. This denotes that the $\mathrm{Fe}(\mathrm{II})$ ions have undergone a SCO transition to the HS state (see below). The organization within the lattice of the components of the $\left[\mathrm{Fe}(\mathrm{Mebpp})_{2-2 x}(\mathrm{Me} 2 \mathrm{bpp})_{2 x}\right]$ $\left(\mathrm{ClO}_{4}\right)_{2}$ systems is analogous for all of the structures analyzed. The species composing the average moiety [Fe$\left.(\mathrm{Mebpp})_{2-2 x}(\mathrm{Me} 2 \mathrm{bpp})_{2 x}\right]^{2+}$ feature two different orientations, each complex interacting with two neighbors with the same orientation and four neighbors with the other orientation. The former contacts through one $\pi \cdots \pi$ and two $\mathrm{C}-\mathrm{H} \cdots \pi$ interactions and gives rise to supramolecular chains of complexes with identical orientation (Figure 4, contacts 13 ). These chains are organized as sheets via three $\mathrm{C}-\mathrm{H} \cdots \pi$ interactions between complexes with different orientations (Figure 4, contacts 4-6). The parallel sheets are approximately perpendicular to the bpp ligands (Figure 4) and thus to the $\mathrm{N}_{\mathrm{py}}-\mathrm{Fe}-\mathrm{N}_{\mathrm{py}}$ axes $\left(\mathrm{N}_{\mathrm{py}}=\mathrm{N}\right.$ donors of the pyridyl fragment of bpp). Intermolecular interactions between the sheets are comparatively much weaker.

Overall, the packing of the $\left[\mathrm{Fe}(\mathrm{Mebpp})_{2-2 x}(\mathrm{Me} 2 \mathrm{bpp})_{2 x}\right]^{2+}$ species with two different orientations is the same as in polymorph $1 \alpha$ of complex 1 and in complex 2 , but not 3. The last complex exhibits the same lattice as polymorph $\mathbf{1} \beta$ (Figure S1). Therefore, the lattice of $\mathbf{2}$ is capable of accommodating increasing amounts of ligand Me2bpp up to $x \approx 0.5$. When this limit is reached, mixtures of crystals of different phases are obtained, indicating that the lattice of $\mathbf{2}$ does not admit larger concentrations of the doping ligand. The above series of SCXRD determinations allow a detailed analysis of the evolution of the main intermolecular interactions present in the lattice (Figure 4 and Table 2) and establish correlations between these and the cooperativity of the SCO (see below). This analysis unveils gradual variations in unit cell parameters with composition changes, including an increase of up to $3.7 \%$ for the cell volume (Figure 5). This is also translated into a gradual variation of the distances defining the main 
Table 1. Relevant Parameters ${ }^{a}$ of the Structure and SCO of $2(x=0),\left[\mathrm{Fe}(\operatorname{Mebpp})_{2-2 x}(\operatorname{Me} 2 \mathrm{bpp})_{2 x}\right]\left(\mathrm{ClO}_{4}\right)_{2}(4 x)$, and $3(x=1)$

\begin{tabular}{|c|c|c|c|c|c|c|c|c|c|c|c|c|}
\hline$x$ & $\begin{array}{l}\text { C12 } \\
(\%)\end{array}$ & $\begin{array}{l}\text { C25 } \\
(\%)\end{array}$ & $\begin{array}{c}\text { "contact 5" } \\
(\AA)\end{array}$ & $\begin{array}{c}\Delta \beta \\
(\operatorname{deg})\end{array}$ & $T_{\text {SCO }}(\mathrm{K})$ & $\Delta T_{80}(\mathrm{~K})$ & $\Gamma / R T_{\mathrm{SCO}}$ & $T_{\text {peak }}(\mathrm{K})$ & $\begin{array}{c}\Delta_{\mathrm{SCO}} H \\
\left(\mathrm{~kJ} \mathrm{~mol}^{-1}\right)\end{array}$ & $\begin{array}{c}\Delta_{\mathrm{SCO}} S \\
\left(\mathrm{~J} \mathrm{~mol}{ }^{-1} \mathrm{~K}^{-1}\right)\end{array}$ & $n^{\text {Sorai }}$ & $T^{\text {Sorai }}(\mathrm{K})$ \\
\hline $0(2)$ & $\mathrm{N} / \mathrm{A}$ & $\mathrm{N} / \mathrm{A}$ & 3.061 & 2.58 & 184.0 & 16.7 & 2.01 & 183.1 & 5.87 & 31.74 & 21.3 & 185.6 \\
\hline 0.05 & 5 & 5 & 3.088 & 2.41 & 184.4 & 36.5 & 1.92 & 184.7 & 4.94 & 26.32 & 15.9 & 185.8 \\
\hline 0.1 & 5 & 15 & 3.135 & 2.13 & 187.5 & 57.4 & 1.70 & 188.1 & 4.85 & 25.09 & 9.4 & 190.3 \\
\hline 0.15 & 12 & 18 & 3.145 & 1.79 & 190.3 & 87.3 & 1.57 & & & & & \\
\hline 0.2 & 17 & 23 & 3.153 & 1.79 & 193.6 & 92.9 & 1.49 & 194.4 & 3.65 & 18.16 & 7.0 & 199.8 \\
\hline 0.3 & 25 & 35 & 3.195 & 1.55 & 198.4 & 106.8 & 1.39 & 201.9 & 3.50 & 17.08 & 5.9 & 208.5 \\
\hline 0.4 & 35 & 45 & 3.273 & 1.19 & 207.3 & 120.4 & 1.36 & 209.8 & 2.99 & 14.10 & 5.8 & 218.9 \\
\hline 0.5 & 37 & 63 & 3.470 & 1.10 & 226.3 & 119.9 & 1.33 & 244.4 & 3.29 & 15.12 & 5.8 & 225.1 \\
\hline $1(3)$ & $\mathrm{N} / \mathrm{A}$ & $\mathrm{N} / \mathrm{A}$ & $\mathrm{N} / \mathrm{A}$ & $\mathrm{N} / \mathrm{A}$ & 381.1 & 70.0 & 1.70 & 375.2 & 14.11 & 37.98 & 9.0 & 375.0 \\
\hline
\end{tabular}

${ }^{a} \mathrm{C} 12$ and $\mathrm{C} 25$ are the occupancies of the 5-methyl substituent from Me2bpp at each ligand position, and contact 5 is the intermolecular contact that suffers the largest variations with increased $x$ (see Figure 4 and the Supporting Information), all at $T=100 \mathrm{~K} . \Delta \beta$ is the total variation of the monoclinic cell angle $\beta$ over the SCO temperature range. The SCO characteristic temperature $T_{\mathrm{SCO}}$ is defined as the temperature at which half of the Fe centers have undergone the transition (i.e., HS fraction $\gamma_{\mathrm{HS}}=0.5$ ). $\Delta T_{80}$ is the temperature range over which $80 \%$ of the SCO is completed. $\Gamma$ is the measure of the SCO cooperativeness derived through the regular solution model (see the Supporting Information). ${ }^{78} T_{\text {peak }}, \Delta_{\mathrm{SCO}} H$, and $\Delta_{\mathrm{SCO}} S$ are the peak temperature and excess enthalpy and entropy, respectively, associated with the SCO anomaly in heat capacity data. $n^{\text {Sorai }}$ and $T^{\text {Sorai }}$ are the domain size and SCO temperature derived through Sorai's domain model (see the Supporting Information).$^{79,80}$ The value of $n^{\text {Sorai }}$ for $x=0$ differs from that previously reported, ${ }^{74}$ as we have considered only the broader anomaly, as it corresponds to the SCO process.

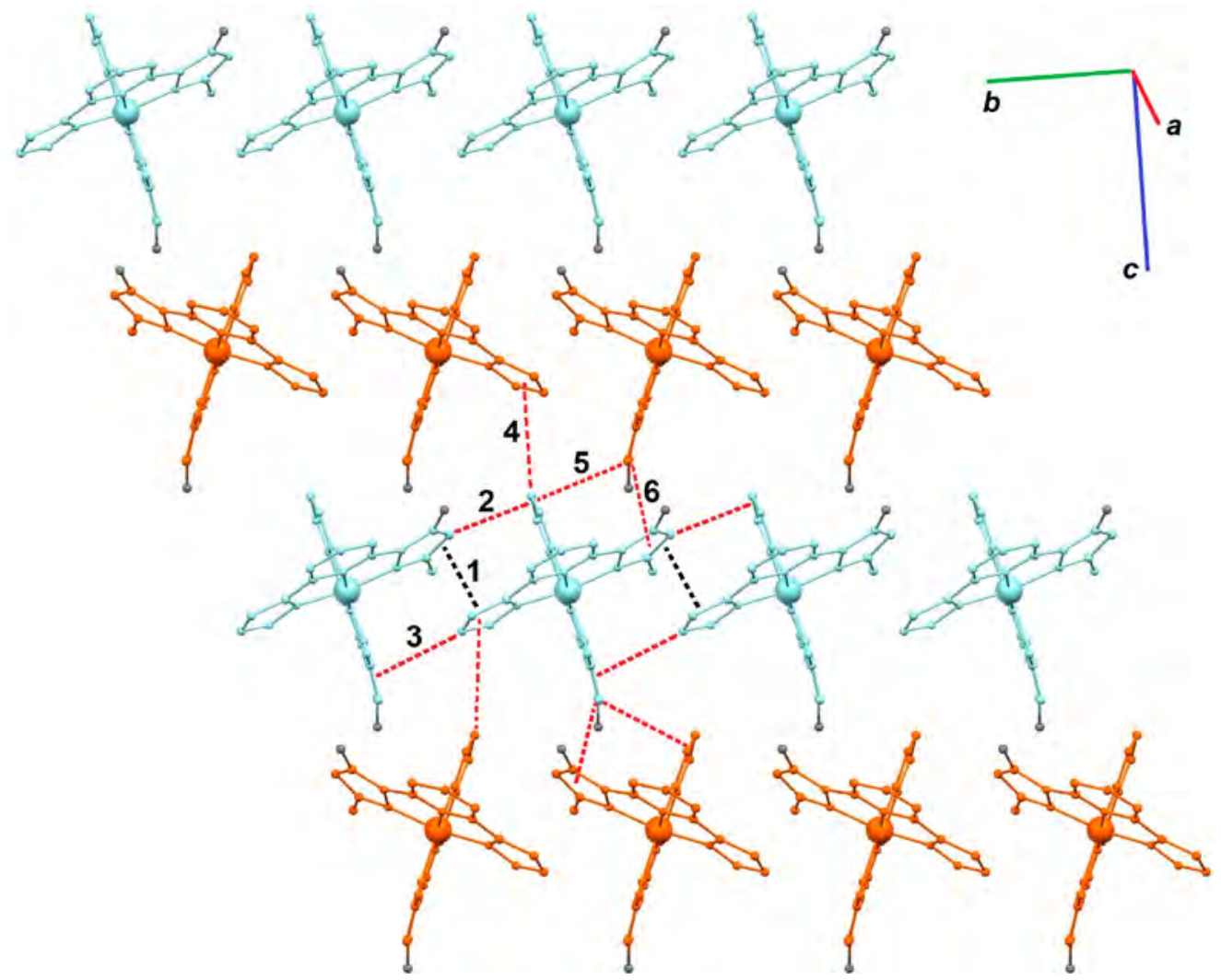

Figure 4. Sheet organization of the cations in all $4 x$ compounds, emphasizing their two different orientations and the relevant $\pi \cdots \pi$ (black dashed lines) and $\mathrm{C}-\mathrm{H} \cdots \pi$ interactions (red dashed lines) formed by each complex with its closest neighbors. The data used correspond to $x=0.5$ ( $T=$ $100 \mathrm{~K})$. The crystallographically independent interactions are labeled 1-6 (Table 2). Supramolecular chains of complexes with identical orientation formed via one $\pi \cdots \pi(1)$ and two $\mathrm{C}-\mathrm{H} \cdots \pi$ (2 and 3) interactions are highlighted through the color of the complex, either light blue or orange. Unit cell axes are shown.

intermolecular interactions (see below and Tables 1 and 2 and Table S3).

Magnetic and Thermal Signatures of SCO and Its Cooperativity. The solid solutions $[\mathrm{Fe}-$ $\left.(\mathrm{Mebpp})_{2-2 x}(\mathrm{Me} 2 \mathrm{bpp})_{2 x}\right]\left(\mathrm{ClO}_{4}\right)_{2}(4 x)$ with $x=0.05,0.1$, $0.15,0.2,0.3,0.4,0.5$ were analyzed between 2 and $300 \mathrm{~K}$ (or $360 \mathrm{~K})$ in the warming and cooling modes, both giving superimposable data for each studied value of $x$. In Figure 6 are represented $\chi T$ vs $T$ plots $(\chi$ is the molar paramagnetic susceptibility per $\mathrm{Fe}(\mathrm{II})$ center for each compound). Pure complex 2, $\left[\mathrm{Fe}(\mathrm{Mebpp})_{2}\right]\left(\mathrm{ClO}_{4}\right)_{2}$, was previously reported to exhibit an abrupt, almost complete $\mathrm{SCO}$ process with $T_{\mathrm{SCO}}=$ $184 \mathrm{~K}^{74}$ Growing proportions of Me2bpp render the SCO curves more gradually, while $T_{\mathrm{SCO}}$ increases progressively (Figure 7 and Table 1). The highest SCO temperature was reached for $x=0.5$ (with $T_{\mathrm{SCO}}=226.3 \mathrm{~K}$ ). As mentioned 
Table 2. Shortest Fe $\cdots$ Fe Intermolecular Separations and $\pi \cdots \pi$ and $\mathrm{C}-\mathrm{H} \cdots \pi$ Intermolecular Short Contacts in the Structures of Compounds $4 x$, Compared to Those of Compound 2 (All at $T=100 \mathrm{~K})^{a}$

\begin{tabular}{lccccccccc}
\multicolumn{1}{c}{$x$} & & & \multicolumn{5}{c}{ contact $(\AA)$} \\
\cline { 5 - 9 } $0(2)$ & $\mathrm{Fe} \cdots \mathrm{Fe}(\AA)^{b}$ & $\mathrm{Fe} \cdots \mathrm{Fe}(\AA)^{c}$ & $\mathrm{Fe} \cdots \mathrm{Fe} \cdots \mathrm{Fe}(\mathrm{deg})$ & 1 & 2 & 3 & 4 & 5 \\
0.05 & 8.045 & 9.490 & 70.1 & 3.187 & 3.566 & 2.583 & 3.313 & 3.061 & 3.156 \\
0.1 & 8.014 & 9.489 & 70.1 & 3.169 & 3.552 & 2.588 & 3.316 & 3.088 & 3.149 \\
0.15 & 8.034 & 9.534 & 70.0 & 3.168 & 3.550 & 2.619 & 3.330 & 3.135 & 3.152 \\
0.2 & 8.011 & 9.526 & 70.2 & 3.144 & & 2.621 & 3.331 & 3.117 & 3.147 \\
0.3 & 8.004 & 9.553 & 70.2 & 3.141 & 3.529 & 2.649 & 3.363 & 3.153 \\
0.4 & 7.980 & 9.606 & 70.0 & 3.138 & 3.517 & 2.644 & 3.388 & 3.195 & 3.142 \\
0.5 & 7.966 & 9.647 & 70.2 & 3.119 & 3.496 & 2.699 & 3.448 & 3.273 & 3.134 \\
& 7.975 & 9.679 & 70.1 & 3.120 & 3.496 & 2.699 & 3.470 & 3.470
\end{tabular}

${ }^{a_{\text {These }}}$ contacts result in supramolecular chains of complexes with the same orientation (contacts 1-3) that organize as parallel sheets (through contacts 4-6); see Figure $4 .{ }^{b}$ Within (i.e., among complexes with the same orientation) supramolecular chains; see Figure 4 and Figure S1. ${ }^{c}$ Between (i.e., between complexes with different orientations) supramolecular chains; see Figure 4 and Figure S1.

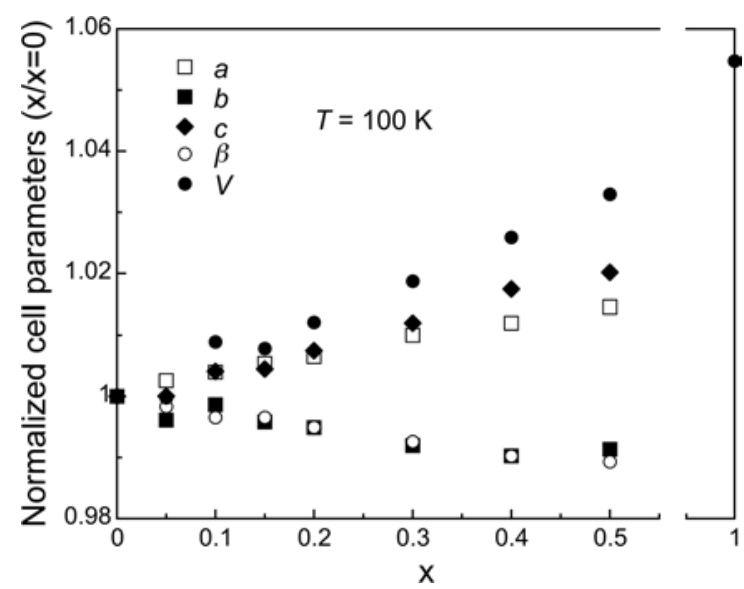

Figure 5. Relative variation of the crystallographic unit cell parameters and volume with the value of $x$ in the structures of the $\left[\mathrm{Fe}(\mathrm{Mebpp})_{2-2 x}(\mathrm{Me} 2 \mathrm{bpp})_{2 x}\right]\left(\mathrm{ClO}_{4}\right)_{2}(2,4 x)$ compounds at $100 \mathrm{~K}$. The volume of the cell of $3(x=1)$ is also included.

above, no alloy could be crystallized beyond this dopant concentration. The phase transitions of compounds $4 x$ were also examined by differential scanning calorimetry (DSC, Figure 6), and the results were consistent with the magnetic susceptibility measurements. Thus, in all cases, anomalies associated with the SCO phenomena were detected in the temperature dependence of the molar heat capacity $C_{p}$ and excess heat capacity $\Delta \mathrm{Cp}$ (Figure S5 and Figure 6, respectively). The maxima of the corresponding peaks shift to higher temperatures as $x$ increases, as seen from the magnetic data (Table 1).

A first measure of the cooperative character of the SCO can be obtained by fitting of the $\Delta C_{\mathrm{p}}$ vs $T$ curves to Sorai's domain model. ${ }^{79,81}$ The number of SCO centers per domain $n$ is found to decrease with increasing $x$ (Table 1, Figure 8, and Figure S6). This confirms and gives an estimate of the loss of cooperativity caused by the doping, the decrease of $n$ being particularly fast at low $x$. This is in line with the evolution with $x$ of the thermodynamic parameters $\Delta_{\mathrm{SCO}} S$ and $\Delta_{\mathrm{SCO}} H$, obtained from the excess heat capacity $\Delta C_{\mathrm{p}}$ (Table 1 and Figure 7). While complex 2 experiences a $\Delta_{\mathrm{SCO}} S$ value much larger than expected from the spin transition electronic process only $\left(R \ln 5=13.38 \mathrm{~J} \mathrm{~mol}^{-1} \mathrm{~K}^{-1}\right)$, suggesting a strong coupling of the system with phonons, the excess entropy diminishes as the dopant concentration grows, depicting the loss of cooperativity. The variation of $\Delta T_{80}$ (temperature range
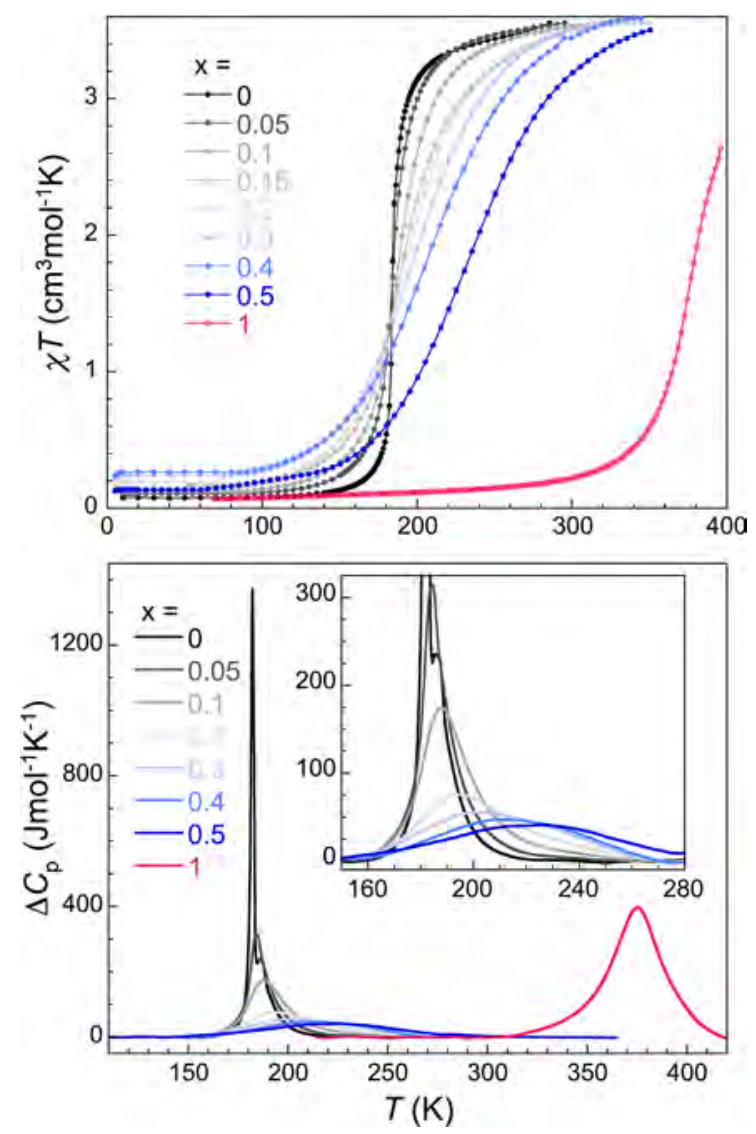

Figure 6. $\chi T$ vs $T$ plots (top) and excess heat capacities (bottom) for the family of compounds $\left[\mathrm{Fe}(\mathrm{Mebpp})_{2-2 x}(\mathrm{Me} 2 \mathrm{bpp})_{2 x}\right]\left(\mathrm{ClO}_{4}\right)_{2}(4 x$, see legend). The data for compounds $2(x=0)$ and $3(x=1)^{74}$ are also included for comparison.

needed to undergo an $80 \%$ conversion in the $\chi T$ vs $T$ curves) with $x$ (Figure 8) also mirrors this decrease in cooperativity. Another estimation of the cooperativity can be derived by fitting the magnetic data to a regular solid solution model, ${ }^{78}$ providing the mean-field interaction term $\Gamma$ (see the Supporting Information and Figure S7). Similarly to $n, \Gamma$ decreases with $x$, more significantly at lower degrees of doping (Table 1 and Figure 8).

Cooperativity-Structure Correlation. The extent to which the local structural effects of the SCO are translated into the lattice parameters has a direct effect on the cooperativity. 

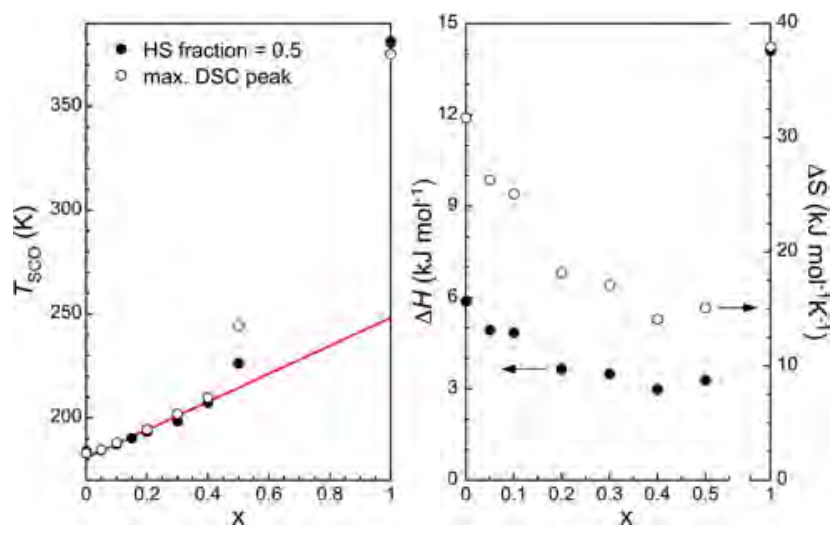

Figure 7. Variation of the SCO parameters, $T_{\mathrm{SCO}}$ and excess enthalpy $\Delta_{\mathrm{SCO}} H$ and entropy $\Delta_{\mathrm{SCO}} S$, as a function of $x$ in compounds $\left[\mathrm{Fe}(\mathrm{Mebpp})_{2-2 x}(\mathrm{Me} 2 \mathrm{bpp})_{2 x}\right]\left(\mathrm{ClO}_{4}\right)_{2}(4 x)$. The data for compounds $\mathbf{2}(x=0)$ and $\mathbf{3}(x=1)$ are also included. The solid red line is a linear dependence with $T_{\mathrm{SCO}}=180.8+67.5 x$.

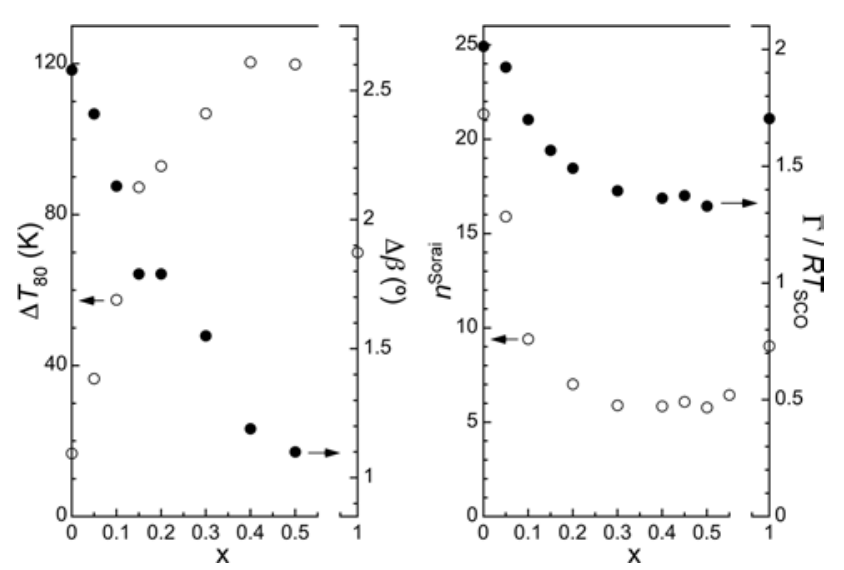

Figure 8. Variation with $x$ of the different parameters (see text) estimating the cooperative character of the SCO in compounds $2(x=$ $0), 4 x$, and $3(x=1)$.

The spin transitions of the $\left[\mathrm{Fe}(\mathrm{Mebpp})_{2-2 x}(\mathrm{Me} 2 \mathrm{bpp})_{2 x}\right]$ $\left(\mathrm{ClO}_{4}\right)_{2}(4 x)$ family were analyzed in more detail by variabletemperature SCXRD, following the temperature dependence of the cell parameters. This study reveals that only the $a$ axis and the monoclinic angle $\beta$ experience some marked changes in addition to those expected from the thermal variation, which can thus be ascribed to the SCO process (Figure S8). This is especially true for the $\beta$ angle, which in all cases experiences a significant increase (by up to $2.5 \%$ ) upon SCO, very similar in shape to the $\chi T$ vs $T$ curve (Figure 8 and Figure S9). The decrease in cooperativity with increasing $x$ is in fact depicted by the associated $\Delta \beta$ (Table 1 and Figure 9), together with more gradual thermal changes of the $\beta$ angle.

Cooperativity changes within the compounds $[\mathrm{Fe}-$ $\left.(\mathrm{Mebpp})_{2-2 x}(\mathrm{Me} 2 \mathrm{bpp})_{2 x}\right]\left(\mathrm{ClO}_{4}\right)_{2}(4 x)$ are undoubtedly related to the modifications of the intermolecular interactions caused with the increase in $x$. The extensive SCXRD study carried out (see above) is of great value to undertake this analysis. Figure 10 shows the variation of average distances defining the main intermolecular interactions between complexes identified in the lattice of compounds $4 x$ (Figure 4 and Table 2), measured as $\mathrm{C}_{\mathrm{pz}} \cdots$ centroid (for the $\mathrm{CH} \cdots \pi$ contacts) or centroid $\cdots$ centroid (for the $\pi \cdots \pi$ interactions) separations. Overall, the inclusion of Me2bpp causes a

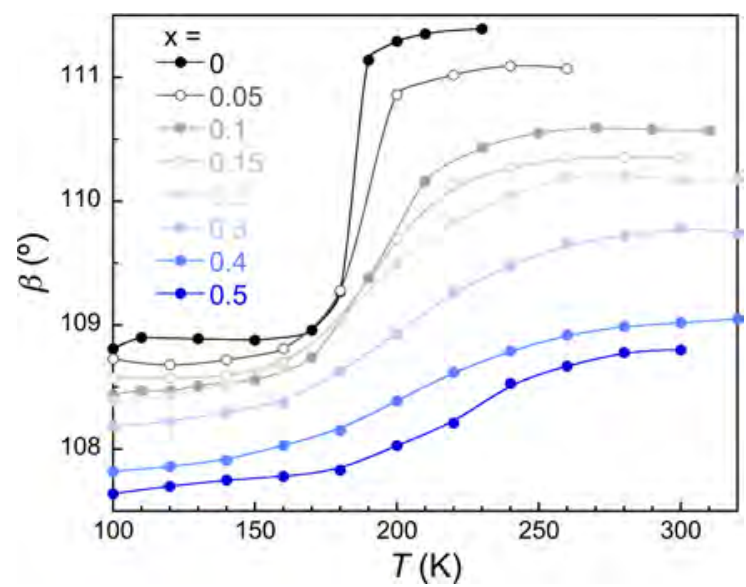

Figure 9. Temperature dependence of the monoclinic cell angle $\beta$ upon the SCO process in compounds 2 and $4 x$.
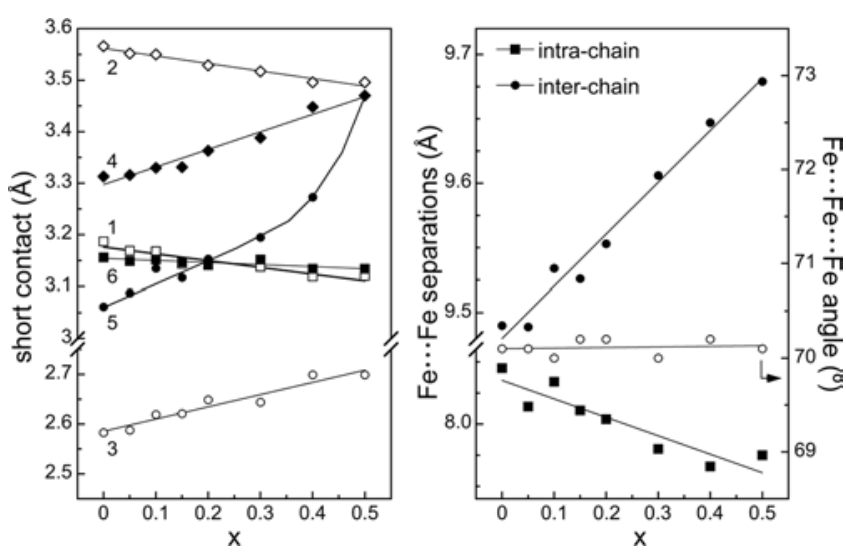

Figure 10. Variation with $x$ of the short contacts describing the main intermolecular interactions between complexes and shortest $\mathrm{Fe} \cdots \mathrm{Fe}$ separations within the isostructural lattice of compounds 2 and $4 x$ (all at $T=100 \mathrm{~K}$; see Tables 1 and 2 and Figure 4 for a definition of contacts).

relatively limited decrease in three parameters and a comparatively larger increase in the other three parameters, especially the $\mathrm{C}-\mathrm{H} \cdots \pi$ interaction " 5 ", which occurs between neighboring supramolecular chains of complexes (Figures 4 and 10 and Tables 1 and 2). This is also depicted by the interchain shortest $\mathrm{Fe} \cdots \mathrm{Fe}$ separation, which significantly increases with $x$ (Figure 10). Interaction " 5 ", precisely, is strongly affected by the additional methyl group borne by the Me2bpp dopant, which explains the fact that it is the most deviant. Thus, the increase in $x$ causes a marked decrease in the intensity of the intermolecular contacts between chains of complexes with identical orientations (Figure 4). This is necessarily relevant for the observed reduced cooperative character of the SCO upon increased doping, considering that it is known that strong cooperativity requires propagation of the molecular structural modifications associated with the SCO to the whole volume of the solid. Most important, however, is that the additional methyl groups borne by the dopant Me2bpp ligands cause a local disruption of some intermolecular interactions (especially contact " 5 ") exerting a more intense effect to the propagation of the elastic interactions in comparison to that revealed by the average evolution shown in Figure 10. This local disruption is most likely at the origin of the drastic decrease in cooperativity observed already for very 
small concentrations of dopant (Figure 8). From $x>0.2$, the cooperativity becomes more stable toward composition changes. The effect of the doping is, in general, similar to that observed on systems doped with isostructural non-SCO complexes. However, the disruption of the propagation of elastic interactions in the latter is different from that here. In the metal-doped systems the weakening of cooperativity is caused by the lack of structural transitions of the nonactive centers. In the current alloys, it is due to the interruption of some intermolecular interactions.

Allosteric SCO. Another effect caused by the Me2bpp dopant of compounds $4 x$ is the increase of $T_{\mathrm{SCO}}$ of the SCO. This increase, close to linear up to $x=0.4\left(T_{\mathrm{SCO}}=180.8+\right.$ $67.5 x)$, occurs at a pace completely different from that of the evolution of the cooperativity described above (Figure 8), which suggests that the causes for the $T_{\mathrm{SCO}}$ dependence differ from these influencing the cooperativity. The increase of $T_{\mathrm{SCO}}$ with $x$ must be explained by the fact that the SCO for $\left[\mathrm{Fe}(\mathrm{Me} 2 \mathrm{bpp})_{2}\right]\left(\mathrm{ClO}_{4}\right)_{2}(3)$ occurs at a temperature higher than for $\left[\mathrm{Fe}(\mathrm{Mebpp})_{2}\right]\left(\mathrm{ClO}_{4}\right)_{2}(2)$ but these were measured on lattices that are not isomorphic. While this precludes a comparison between both solids, it was also found that in solution $T_{\mathrm{SCO}}\left(\right.$ of 3 ) $>T_{\mathrm{SCO}}$ ( of 2), although the values are closer $\left(232\right.$ and $281 \mathrm{~K}$, respectively; $\left.\Delta T_{\mathrm{SCO}}=49 \mathrm{~K}\right) .{ }^{74}$ Part of the increase in $T_{\mathrm{SCO}}$ must therefore be ascribed to the effects caused by the additional methyl substituent, as previously reported for the pure complexes 2 and $3 .^{74}$ This renders an increase in $T_{\mathrm{SCO}}$ with growing concentrations of Me2bpp analogous to that observed for the $\mathrm{Fe}(\mathrm{Htrz})_{3-3 x}\left(4-\mathrm{NH}_{2} \operatorname{trz}\right)_{3 x}$. $\left(\mathrm{ClO}_{4}\right)_{2}$ system. ${ }^{71}$ It must be noted, however, that compounds $4 x$ are made of discrete complexes (not coordination polymers), for which there are no such strong short-range interactions as in the triazole-based 1D polymers which force the SCO centers within the chain to behave cooperatively. Therefore, one could expect to observe a SCO step for each of the three complexes present in the alloy, even though the effect of the difference in local ligand-field strength may be reduced by the overall long-range interactions. Since all of the SCO curves feature a sole step, the increase in $T_{\mathrm{SCO}}$ must also involve the positive pressure induced on the $\left[\mathrm{Fe}(\mathrm{Mebpp})_{2}\right]^{2+}$ complexes of the lattice by the other two species ([Fe$(\mathrm{Mebpp})(\mathrm{Me} 2 \mathrm{bpp})]^{2+}$ and $\left.\left[\mathrm{Fe}(\mathrm{Me} 2 \mathrm{bpp})_{2}\right]^{2+}\right)$ expected to undergo $\mathrm{SCO}$ at higher temperature. Once the positive pressure is overcome, the SCO occurs in a concerted manner (at a temperature lower than that expected for the species containing Me2bpp) as a result of an allosteric effect, ${ }^{68}$ where the $\mathrm{SCO}$ of the $\left[\mathrm{Fe}(\mathrm{Mebpp})_{2}\right]^{2+}$ centers induces the transition of the other two complexes present in the lattice. This is reminiscent of the synergy observed between SCO Fe(II) and $\mathrm{Fe}$ (III) anionic and cationic coordination species of a complex salt. ${ }^{82}$ To the best of our knowledge, the SCO of only Fe(II) complexes induced by an allosteric effect within the lattice of molecular alloys has never been observed before.

\section{CONCLUSIONS}

The crystal lattice of the complex $\left[\mathrm{Fe}(\mathrm{Mebpp})_{2}\right]\left(\mathrm{ClO}_{4}\right)_{2}(2)$ is capable of admitting increasing amounts of ligand Me2bpp, leading to the formation of molecular alloys with the composition $\left[\mathrm{Fe}(\mathrm{Mebpp})_{2-2 x}(\mathrm{Me} 2 \mathrm{bpp})_{2 x}\right]\left(\mathrm{ClO}_{4}\right)_{2}(4 x)$, only up to $x=0.5$. The increase of $x$ causes a decrease in the cooperativity of the SCO of this molecular system, noticed very suddenly for very low values of $x$. This is caused by the interruption of some intermolecular interactions due to the presence of the additional methyl substituent of the dopant ligand and to gradual average changes to these interactions. The mean variation of the intermolecular interaction parameters has been determined by SCXRD, to an unprecedented level of detail for SCO molecular alloys. The doping also causes an increase in the characteristic temperature of the spin transition. Following the previous information on the SCO temperatures of compounds $\left[\mathrm{Fe}(\mathrm{Mebpp})_{2}\right]\left(\mathrm{ClO}_{4}\right)_{2}$ (2) and $\left[\mathrm{Fe}(\mathrm{Me} 2 \mathrm{bpp})_{2}\right]\left(\mathrm{ClO}_{4}\right)_{2}(3)$, it is concluded that this increase is the result of the chemical pressure caused by the presence in the lattice of the species $[\mathrm{Fe}(\mathrm{Mebpp})(\mathrm{Me} 2 \mathrm{bpp})]^{2+}$ and $\left[\mathrm{Fe}(\mathrm{Me} 2 \mathrm{bpp})_{2}\right]^{2+}$, expected to have a higher $T_{\mathrm{SCO}}$. In addition, the observation of concerted, one-step magnetic transitions for all compositions of the studied $4 x$ alloys is most likely the result of a unique allosteric effect where SCO of the $\left[\mathrm{Fe}(\mathrm{Mebpp})_{2}\right]^{2+}$ species is retarded but pushes the premature transitions of the other two species of the alloy. This study unveils a convenient method for tuning the SCO temperature of a molecular material over a range of $42 \mathrm{~K}$.

\section{ASSOCIATED CONTENT}

\section{SI Supporting Information}

The Supporting Information is available free of charge at https://pubs.acs.org/doi/10.1021/acs.inorgchem.0c01061.

Crystallographic details and additional structural views and variation of cell parameters, mass spectroscopy data, analysis of SCO behavior, and heat capacity data (PDF)

\section{Accession Codes}

CCDC 1993012-1993019 contain the supplementary crystallographic data for this paper. These data can be obtained free of charge via www.ccdc.cam.ac.uk/data_request/cif, or by emailing data_request@ccdc.cam.ac.uk, or by contacting The Cambridge Crystallographic Data Centre, 12 Union Road, Cambridge CB2 1EZ, UK; fax: +44 1223336033.

\section{AUTHOR INFORMATION}

\section{Corresponding Authors}

Carlos Bartual-Murgui - Departament de Química Inorgànica i Orgànica, Universitat de Barcelona, 08028 Barcelona, Spain; 주 orcid.org/0000-0003-1547-8018; Email: Carlos.Bartual@ uv.es

Olivier Roubeau - Instituto de Ciencia de Materiales de Aragón (ICMA), CSIC and Universidad de Zaragoza, 50009

Zaragoza, Spain; 이이. ord/0000-0003-2095-5843;

Email: roubeau@unizar.es

Guillem Aromí - Departament de Química Inorgànica $i$ Orgànica, Universitat de Barcelona, 08028 Barcelona, Spain; Institute of Nanoscience and Nanotechnology of the University of Barcelona (IN2UB), Barcelona, Spain;

Email: guillem.aromi@qi.ub.es

\section{Authors}

Cristian Pérez-Padilla - Departament de Química Inorgànica $i$ Orgànica, Universitat de Barcelona, 08028 Barcelona, Spain

Simon J. Teat - Advanced Light Source, Berkeley Laboratory, Berkeley, California 94720, United States

Complete contact information is available at: https://pubs.acs.org/10.1021/acs.inorgchem.0c01061

\section{Author Contributions}

C.B-M. and C.P-P. did all the synthetic work and chemical characterization, C.B-M., O.R., and S.T. worked on the 
structural characterization, C.B-M. and O.R. worked on the magnetic characterization, and O.R. performed the calorimetry and analysis of all data. O.R. and G.A. wrote the manuscript with contributions from the rest of the authors. All authors have given approval to the final version of the manuscript.

\section{Notes}

The authors declare no competing financial interest.

\section{ACKNOWLEDGMENTS}

G.A. thanks the Generalitat de Catalunya for the prize ICREA Academia 2018 and QUANTERA for project SUMO (through PCI2018-093106). The authors acknowledge funding by the Spanish MINECO through CTQ2015-68370-P and PGC2018-098630-B-I00 (G.A. and C.B-M.) and MAT201786826-R (O.R.). This research used resources of the Advanced Light Source, which is a DOE Office of Science User Facility under contract no. DE-AC02-05CH11231 (S.J.T.).

\section{ABBREVIATIONS}

SCO, spin crossover; HS, high spin; LS, low spin; MALDITOF, Matrix-Assisted Laser Desorption/Ionization-time of flight; MS, mass spectrometry; SCXRD, single-crystal X-ray diffraction; PXRD, powder X-ray diffraction; DSC, differential scanning calorimetry

\section{REFERENCES}

(1) Halcrow, M. A. Spin-Crossover Materials: Properties and Applications; Wiley: West Sussex, UK, 2013.

(2) Gütlich, P.; Goodwin, H. A. Spin Crossover in Transition Metal Compounds I-III; Springer: Berlin, 2004; Vols. 233-235.

(3) Gütlich, P.; Hauser, A.; Spiering, H. Thermal and optical switching of iron(II) complexes. Angew. Chem., Int. Ed. Engl. 1994, 33, 2024-2054.

(4) Bousseksou, A.; Molnár, G.; Salmon, L.; Nicolazzi, W. Molecular spin crossover phenomenon: recent achievements and prospects. Chem. Soc. Rev. 2011, 40, 3313-3335.

(5) Saha, S.; Stoddart, J. F. Photo-driven molecular devices. Chem. Soc. Rev. 2007, 36, 77-92.

(6) Bogani, L.; Wernsdorfer, W. Molecular spintronics using singlemolecule magnets. Nat. Mater. 2008, 7, 179-186.

(7) Gamez, P.; Costa, J. S.; Quesada, M.; Aromí, G. Iron SpinCrossover compounds: from fundamental studies to practical applications. Dalton Trans. 2009, 7845-7853.

(8) Gütlich, P.; Gaspar, A. B.; Garcia, Y. Spin state switching in iron coordination compounds Beilstein. Beilstein J. Org. Chem. 2013, 9, 342-391.

(9) Hogue, R. W.; Singh, S.; Brooker, S. Spin crossover in discrete polynuclear iron(II) complexes. Chem. Soc. Rev. 2018, 47, 73037338.

(10) Collet, E.; Guionneau, P. Structural analysis of spin-crossover materials: From molecules to materials. C. R. Chim. 2018, 21, 11331151 .

(11) Bartual-Murgui, C.; Diego, R.; Vela, S.; Teat, S. J.; Roubeau, O.; Aromí, G. A Spin-Crossover Molecular Material Describing Four Distinct Thermal Pathways. Inorg. Chem. 2018, 57, 11019-11026.

(12) Ortega-Villar, N.; Muñoz, M. C.; Real, J. A. Symmetry Breaking in Iron(II) Spin-Crossover Molecular Crystals. Magnetochemistry 2016, 2, 2.

(13) Phonsri, W.; Davies, C. G.; Jameson, G. N. L.; Moubaraki, B.; Ward, J. S.; Kruger, P. E.; Chastanet, G.; Murray, K. S. Symmetry breaking above room temperature in an $\mathrm{Fe}$ (II) spin crossover complex with an $\mathrm{N}_{4} \mathrm{O}_{2}$ donor set. Chem. Commun. 2017, 53, 1374-1377.

(14) Shatruk, M.; Phan, H.; Chrisostomo, B. A.; Suleimenova, A. Symmetry-breaking structural phase transitions in spin crossover complexes. Coord. Chem. Rev. 2015, 289-290, 62-73.
(15) Arcis-Castíllo, Z.; Zheng, S.; Siegler, M. A.; Roubeau, O.; Bedoui, S.; Bonnet, S. Tuning the Transition Temperature and Cooperativity of bapbpy-Based Mononuclear Spin-Crossover Compounds: Interplay between Molecular and Crystal Engineering. Chem. - Eur. J. 2011, 17, 14826-14836.

(16) Halcrow, M. A. Spin-crossover Compounds with Wide Thermal Hysteresis. Chem. Lett. 2014, 43, 1178-1188.

(17) Halcrow, M. A. Structure:function relationships in molecular spin-crossover complexes. Chem. Soc. Rev. 2011, 40, 4119-4142.

(18) Bao, X.; Leng, J.-D.; Meng, Z.-S.; Lin, Z.; Tong, M.-L.; Nihei, M.; Oshio, H. Tuning the Spin States of Two Apical Iron(II) Ions in the Trigonal-Bipyramidal $\left[\left\{\mathrm{Fe}^{\mathrm{II}}(\mu \text {-bpt })_{3}\right\}_{2} \mathrm{Fe}^{\mathrm{II}}{ }_{3}\left(\mu^{3}-\mathrm{O}\right)\right]^{2+}$ Cations Through the Choice of Anions. Chem. - Eur. J. 2010, 16, 6169-6174.

(19) Fujinami, T.; Nishi, K.; Matsumoto, N.; Iijima, S.; Halcrow, M. A.; Sunatsuki, Y.; Kojima, M. 1D and 2D assembly structures by imidazole $\cdots$ chloride hydrogen bonds of iron(II) complexes $\left[\mathrm{Fe}^{\mathrm{II}}(\mathrm{HLn}-\mathrm{Pr})_{3}\right] \mathrm{Cl} \cdot \mathrm{Y}(\mathrm{HLn}-\mathrm{Pr}=2$-methylimidazol-4-yl-methylideneamino-n-propyl; $\left.\mathrm{Y}=\mathrm{AsF}_{6}, \mathrm{BF}_{4}\right)$ and their spin states. Dalton Trans. 2011, 40, 12301-12309.

(20) Yamada, M.; Ooidemizu, M.; Ikuta, Y.; Osa, S.; Matsumoto, N.; Iijima, S.; Kojima, M.; Dahan, F.; Tuchagues, J.-P. Interlayer Interaction of Two-Dimensional Layered Spin Crossover Complexes $\left[\mathrm{Fe}^{\mathrm{II}} \mathrm{H}_{3} \mathrm{~L}^{\mathrm{Me}}\right]\left[\mathrm{Fe}^{\mathrm{II}} \mathrm{L}^{\mathrm{Me}}\right] \mathrm{X}\left(\mathrm{X}^{-}=\mathrm{ClO}_{4}^{-}, \mathrm{BF}_{4}^{-}, \mathrm{PF}_{6}^{-}, \mathrm{AsF}_{6}{ }^{-}\right.$, and $\mathrm{SbF}_{6}{ }^{-}$; $\mathrm{H}_{3} \mathrm{LMe}=\operatorname{Tris}[2-(((2-$ methylimidazol-4-yl $)$ methylidene $)$ amino $)-$ ethyl] amine). Inorg. Chem. 2003, 42, 8406-8416.

(21) Quesada, M.; Prins, F.; Bill, E.; Kooijman, H.; Gamez, P.; Roubeau, O.; Spek, A. L.; Haasnoot, J. G.; Reedijk, J. Counterion Effect on the Spin-Transition Properties of the Cation $\left[\mathrm{Fe}(\mathrm{btzx})_{3}\right]^{2+}$ $($ btzx $=\mathrm{m}$-Xylylenebis(tetrazole $))$. Chem. - Eur. J. 2008, 14, 84868499.

(22) Knoll, C.; Muller, D.; Seifried, M.; Giester, G.; Welch, J. M.; Artner, W.; Hradil, K.; Reissner, M.; Weinberger, P. Cooperativity in spin crossover materials as ligand's responsibility - investigations of the $\mathrm{Fe}(\mathrm{II})-1,3$-bis $((1 \mathrm{H}$-tetrazol-1-yl $)$ methyl $)$ bicyclo 1.1 .1 pentane system. Dalton Trans. 2018, 47, 5553-5557.

(23) Craig, G. A.; Costa, J. S.; Roubeau, O.; Teat, S. J.; Aromí, G. Local Coordination Geometry and Spin State in Novel Fe ${ }^{\mathrm{II}}$ Complexes with 2,6-Bis(pyrazol-3-yl)pyridine-Type Ligands as Controlled by Packing Forces: Structural Correlations. Chem. - Eur. J. 2012, 18, 11703-11715.

(24) Fumanal, M.; Jiménez-Grávalos, F.; Ribas-Ariño, J.; Vela, S. Lattice-Solvent Effects in the Spin-Crossover of an Fe(II)-Based Material. The Key Role of Intermolecular Interactions between Solvent Molecules. Inorg. Chem. 2017, 56, 4474-4483.

(25) Roberts, T. D.; Tuna, F.; Malkin, T. L.; Kilner, C. A.; Halcrow, M. A. An iron(II) complex exhibiting five anhydrous phases, two of which interconvert by spin-crossover with wide hysteresis. Chem. Sci. 2012, 3, 349-354.

(26) Halder, G. J.; Kepert, C. J.; Moubaraki, B.; Murray, K. S.; Cashion, J. D. Guest-Dependent Spin Crossover in a Nanoporous Molecular Framework Material. Science 2002, 298, 1762.

(27) Quesada, M.; de la Peña-O'Shea, V. A.; Aromí, G.; Geremia, S.; Massera, C.; Roubeau, O.; Gamez, P.; Reedijk, J. A molecule-based nanoporous material showing tuneable spin-crossover behavior near room temperature. Adv. Mater. 2007, 19, 1397-1402.

(28) Bonnet, S.; Molnár, G.; Sanchez Costa, J.; Siegler, M. A.; Spek, A. L.; Bousseksou, A.; Fu, W.-T.; Gamez, P.; Reedijk, J. Influence of Sample Preparation, Temperature, Light, and Pressure on the TwoStep Spin Crossover Mononuclear Compound [Fe(bapbpy)(NCS)2]. Chem. Mater. 2009, 21, 1123-1136.

(29) Wei, R.-J.; Tao, J.; Huang, R.-B.; Zheng, L.-S. Reversible and Irreversible Vapor-Induced Guest Molecule Exchange in SpinCrossover Compounds. Inorg. Chem. 2011, 50, 8553-8564.

(30) Zhang, W.; Zhao, F.; Liu, T.; Yuan, M.; Wang, Z.-M.; Gao, S. Spin Crossover in a Series of Iron(II) Complexes of 2-(2-Alkyl-2Htetrazol-5-yl)-1,10-phenanthroline: Effects of Alkyl Side Chain, Solvent, and Anion. Inorg. Chem. 2007, 46, 2541-2555.

(31) Sertphon, D.; Harding, P.; Murray, K.; Moubaraki, B.; Neville, S.; Liu, L.; Telfer, S.; Harding, D. Solvent Effects on the Spin 
Crossover Properties of Iron(II) Imidazolylimine Complexes. Crystals 2019, 9, 116.

(32) Weber, B.; Kaps, E.; Weigand, J.; Carbonera, C.; Létard, J.-F.; Achterhold, K.; Parak, F. G. Cooperative Iron(II) Spin Crossover Complexes with $\mathrm{N}_{4} \mathrm{O}_{2}$ Coordination Sphere. Inorg. Chem. 2008, 47, 487-496.

(33) Halcrow, M. A. Iron(II) complexes of 2,6-di(pyrazol-1yl)pyridines-A versatile system for spin-crossover research. Coord. Chem. Rev. 2009, 253, 2493-2514.

(34) Craig, G. A.; Roubeau, O.; Aromí, G. Spin state switching in 2,6-bis(pyrazol-3-yl)pyridine (3-bpp) based Fe(II) complexes. Coord. Chem. Rev. 2014, 269, 13-31.

(35) Elhaïk, J.; Money, V. A.; Barrett, S. A.; Kilner, C. A.; Evans, I. R.; Halcrow, M. A. The spin-states and spin-crossover behaviour of iron(II) complexes of 2,6-dipyrazol-1-ylpyrazine derivatives. Dalton Trans. 2003, 2053-2060.

(36) Olguín, J.; Brooker, S. Spin crossover active iron(II) complexes of selected pyrazole-pyridine/pyrazine ligands. Coord. Chem. Rev. 2011, 255, 203-240.

(37) Bartual-Murgui, C.; Codina, C.; Roubeau, O.; Aromí, G. A Sequential Method to Prepare Polymorphs and Solvatomorphs of $\mathrm{Fe}(1,3-\mathrm{bpp})(2)$ (ClO4)(2)center dot $\mathrm{nH}(2) \mathrm{O}(\mathrm{n}=0,1,2)$ with Varying Spin-Crossover Behaviour. Chem. - Eur. J. 2016, 22, 1276712776.

(38) Tao, J.; Wei, R.-J.; Huang, R.-B.; Zheng, L.-S. Polymorphism in spin-crossover systems. Chem. Soc. Rev. 2012, 41, 703-737.

(39) Wei, R.-J.; Li, B.; Tao, J.; Huang, R.-B.; Zheng, L.-S.; Zheng, Z. Making Spin-Crossover Crystals by Successive Polymorphic Transformations. Inorg. Chem. 2011, 50, 1170-1172.

(40) Bartual-Murgui, C.; Piñeiro-López, L.; Valverde-Muñoz, F. J.; Muñoz, M. C.; Seredyuk, M.; Real, J. A. Chiral and Racemic Spin Crossover Polymorphs in a Family of Mononuclear Iron(II) Compounds. Inorg. Chem. 2017, 56, 13535-13546.

(41) Miller, R. G.; Brooker, S. Reversible quantitative guest sensing via spin crossover of an iron(II) triazole. Chem. Sci. 2016, 7, 25012505.

(42) Valverde-Muñoz, F. J.; Seredyuk, M.; Meneses-Sánchez, M.; Muñoz, M. C.; Bartual-Murgui, C.; Real, J. A. Discrimination between two memory channels by molecular alloying in a doubly bistable spin crossover material. Chem. Sci. 2019, 10, 3807-3816.

(43) Sorai, M.; Ensling, J.; Gütlich, P. Mössbauer effect study on low-spin ${ }^{1} \mathrm{~A}_{1} \rightleftharpoons$ high-spin ${ }^{5} \mathrm{~T}_{2}$ transition in tris (2-picolylamine) iron chloride I. Dilution effect in $\left[\mathrm{Fe}_{\mathrm{x}} \mathrm{Zn}_{1-\mathrm{x}}(2 \text {-pic) })_{3}\right] \mathrm{Cl}_{2} \cdot \mathrm{C}_{2} \mathrm{H}_{5} \mathrm{OH}$. Chem. Phys. 1976, 18, 199-209.

(44) Gütlich, P.; Link, R.; Steinhaeuser, H. G. Mössbauer-effect study of the thermally induced spin transition in tris(2-picolylamine)iron(II) chloride. Dilution effect in mixed crystals of $\left[\mathrm{Fe}_{\mathrm{x}} \mathrm{Zn}_{1-\mathrm{x}}(2-\right.$ pic) $\left.{ }_{3}\right] \mathrm{Cl}_{2} \cdot \mathrm{C}_{2} \mathrm{H}_{5} \mathrm{OH}(\mathrm{x}=0.15,0.029,0.0009)$. Inorg. Chem. 1978, 17, 2509-2514.

(45) Haddad, M. S.; Federer, W. D.; Lynch, M. W.; Hendrickson, D. $\mathrm{N}$. An explanation of unusual properties of spin-crossover ferric complexes. J. Am. Chem. Soc. 1980, 102, 1468-1470.

(46) Hauser, A.; Gütlich, P.; Spiering, H. High-spin $\rightarrow$ low-spin relaxation kinetics and cooperative effects in the hexakis(1propyltetrazole)iron bis(tetrafluoroborate) and $\left[\mathrm{Zn}_{1-\mathrm{x}} \mathrm{Fe}_{\mathrm{x}}(\mathrm{ptz})_{6}\right]$ $\left(\mathrm{BF}_{4}\right)_{2}(\mathrm{ptz}=1$-propyltetrazole $)$ spin-crossover systems. Inorg. Chem. 1986, 25, 4245-4248.

(47) Martin, J.-P.; Zarembowitch, J.; Bousseksou, A.; Dworkin, A.; Haasnoot, J. G.; Varret, F. Solid State Effects on Spin Transitions: Magnetic, Calorimetric, and Mössbauer-Effect Properties of $\left[\mathrm{Fe}_{\mathrm{x}} \mathrm{Co}_{1-\mathrm{x}}\left(4,4^{\prime} \text {-bis-1,2,4-triazole }\right)_{2}(\mathrm{NCS})_{2}\right] \cdot \mathrm{H}_{2} \mathrm{O}$ Mixed-Crystal Compounds. Inorg. Chem. 1994, 33, 6325-6333.

(48) Martin, J.-P.; Zarembowitch, J.; Dworkin, A.; Haasnoot, J. G.; Codjovi, E. Solid-State Effects in Spin Transitions: Influence of Iron(II) Dilution on the Magnetic and Calorimetric Properties of the Series $\left[\mathrm{Fe}_{\mathrm{x}} \mathrm{Ni}_{1-\mathrm{x}}\left(4,4^{\prime} \text {-bis }(1,2,4 \text {-triazole })\right)_{2}(\mathrm{NCS})_{2}\right] \cdot \mathrm{H}_{2} \mathrm{O}$. Inorg. Chem. 1994, 33, 2617-2623.
(49) Janiak, C.; Scharmann, T. G.; Bräuniger, T.; Holubová, J.; Nádvorník, M. Spin Crossover Studies on Bis\{hydro-tris $(1,2,4-$ triazolyl)borato \}iron(II). Z. Anorg. Allg. Chem. 1998, 624, 769-774. (50) Chakraborty, P.; Enachescu, C.; Walder, C.; Bronisz, R.; Hauser, A. Thermal and Light-Induced Spin Switching Dynamics in the 2D Coordination Network of $\left\{\left[\mathrm{Zn}_{1-\mathrm{x}} \mathrm{Fe}_{\mathrm{x}}(\mathrm{bbtr})_{3}\right]\left(\mathrm{ClO}_{4}\right)_{2}\right\} \infty$ : The Role of Cooperative Effects. Inorg. Chem. 2012, 51, 9714-9722.

(51) Zheng, S.; Siegler, M. A.; Sánchez Costa, J.; Fu, W.-T.; Bonnet, S. Effect of Metal Dilution on the Thermal Spin Transition of $\left[\mathrm{Fe}_{\mathrm{x}} \mathrm{Zn}_{1-\mathrm{x}}(\right.$ bapbpy $\left.)(\mathrm{NCS})_{2}\right]$. Eur. J. Inorg. Chem. 2013, 2013, 10331042.

(52) Ganguli, P.; Gütlich, P.; Müller, E. W. Effect of metal dilution on the spin-crossover behavior in $\left[\mathrm{Fe}_{\mathrm{x}} \mathrm{M}_{1-\mathrm{x}}(\text { phen })_{2}(\mathrm{NCS})_{2}\right](\mathrm{M}=\mathrm{Mn}$, $\mathrm{Co}, \mathrm{Ni}, \mathrm{Zn})$. Inorg. Chem. 1982, 21, 3429-3433.

(53) Adler, P.; Wiehl, L.; Meibner, E.; Köhler, C. P.; Spiering, H.; Gütlich, P. The influence of the lattice on the spin transition in solids. Investigations of the high spin ag low spin transition in mixed crystals of $\left[\mathrm{Fe}_{\mathrm{x}} \mathrm{M}_{1-\mathrm{x}}(2-\mathrm{pic})_{3}\right] \mathrm{Cl}_{2} \cdot \mathrm{MeOH}$. J. Phys. Chem. Solids 1987, 48, 517525 .

(54) Sanner, I.; Meissner, E.; Köppen, H.; Spiering, H.; Gütlich, P. The Metal dilution effect on the High-spin $\left({ }^{5} \mathrm{~T}_{2}\right) \leftrightarrows$ Low-Spin $\left({ }^{1} \mathrm{~A}_{1}\right)$ Transition in $\left[\mathrm{Fe}_{\mathrm{x}} \mathrm{Co}_{1-\mathrm{x}}(2 \text {-pic) })_{3}\right] \mathrm{Cl}_{2} \mathrm{EtOH}$. Chem. Phys. 1984, 86, 227-233.

(55) Jakobi, R.; Spiering, H.; Wiehl, L.; Gmelin, E.; Gütlich, P. Thermoanalytic investigations on mixed crystals of the spin-crossover system $\left[\mathrm{Fe}_{\mathrm{x}} \mathrm{Zn}_{1-\mathrm{x}}\left(2 \text {-pic- } \mathrm{ND}_{2}\right)_{3}\right] \mathrm{Cl}_{2}$. EtOD. Inorg. Chem. 1988, 27, $1823-1827$.

(56) Baldé, C.; Desplanches, C.; Gütlich, P.; Freysz, E.; Létard, J. F. Effect of the metal dilution on the thermal and light-induced spin transition in $\left[\mathrm{Fe}_{\mathrm{x}} \mathrm{Mn}_{1-\mathrm{x}}(\mathrm{bpp})_{2}\right](\mathrm{NCSe})_{2}$ : When $\mathrm{T}(\mathrm{LIESST})$ reaches $\mathrm{T}_{1 / 2}$. Inorg. Chim. Acta 2008, 361, 3529-3533.

(57) Baldé, C.; Desplanches, C.; Wattiaux, A.; Guionneau, P.; Gütlich, P.; Létard, J.-F. Effect of metal dilution on the light-induced spin transition in $\left[\mathrm{Fe}_{\mathrm{x}} \mathrm{Zn}_{1-\mathrm{x}}(\text { phen })_{2}(\mathrm{NCS})_{2}\right]$ (phen = 1,10-phenanthroline). Dalton Trans. 2008, 2702-2707.

(58) Buchen, T.; Poganiuch, P.; Gütlich, P. Effect of metal dilution on the thermal and light-induced spin transition in $\left[\mathrm{Fe}_{\mathrm{x}} \mathrm{Zn}_{1 .} \mathrm{x}(\mathrm{mtz})_{6}\right]$ $\left[\mathrm{ClO}_{4}\right]_{2}(\mathrm{mtz}=1$-methyl-1H-tetrazole). J. Chem. Soc., Dalton Trans. 1994, 2285-2288.

(59) Tayagaki, T.; Galet, A.; Molnár, G.; Muñoz, M. C.; Zwick, A.; Tanaka, K.; Real, J.-A.; Bousseksou, A. Metal Dilution Effects on the Spin-Crossover Properties of the Three-Dimensional Coordination Polymer Fe(pyrazine) $\left[\mathrm{Pt}(\mathrm{CN})_{4}\right]$. J. Phys. Chem. B 2005, 109, 1485914867.

(60) Tanasa, R.; Enachescu, C.; Stancu, A.; Varret, F.; Linares, J.; Codjovi, E. Study of impurities effect in spin crossover compounds using first order reversal curves (FORC) method. Polyhedron 2007, $26,1820-1824$

(61) Baldé, C.; Desplanches, C.; Grunert, M.; Wei, Y.; Gütlich, P.; Létard, J.-F. Influence of Metal Dilution on the Light-Induced Spin Transition in Two 1D Chain Compounds: [FexZn1-x(btzp)3](BF4) 2 and $\left[\mathrm{Fe}_{\mathrm{x}} \mathrm{Zn}_{1-\mathrm{x}}(\text { endi) })_{3}\right]\left(\mathrm{BF}_{4}\right)_{2} \quad$ btzp $=1,2$-Bis(tetrazol-1yl)propane and endi $=1,2-\mathrm{Bis}($ tetrazol-1-yl)ethane $\}$. Eur. J. Inorg. Chem. 2008, 2008, 5382-5389.

(62) Yu, Z.; Kuroda-Sowa, T.; Kume, H.; Okubo, T.; Maekawa, M.; Munakata, M. Effects of Metal Doping on the Spin-Crossover Properties of an Iron(II) Complex with Extended $\pi$-Conjugated Schiff-Base Ligand Having an N4O2 Donor Set. Bull. Chem. Soc. Jpn. 2009, 82, 333-337.

(63) Rotaru, A.; Dîrtu, M. M.; Enachescu, C.; Tanasa, R.; Linares, J.; Stancu, A.; Garcia, Y. Calorimetric measurements of diluted spin crossover complexes $\left[\mathrm{Fe}_{\mathrm{x}} \mathrm{M}_{1-\mathrm{x}}(\mathrm{btr})_{2}(\mathrm{NCS})_{2}\right] \cdot \mathrm{H}_{2} \mathrm{O}$ with $\mathrm{M}^{\mathrm{II}}=\mathrm{Zn}$ and Ni. Polyhedron 2009, 28, 2531-2536.

(64) Paradis, N.; Chastanet, G.; Létard, J.-F. When Stable and Metastable HS States Meet in Spin-Crossover Compounds. Eur. J. Inorg. Chem. 2012, 2012, 3618-3624.

(65) Baldé, C.; Desplanches, C.; Le Gac, F.; Guionneau, P.; Létard, J.-F. The role of iron(II) dilution in the magnetic and photomagnetic 
properties of the series $\left[\mathrm{Fe}_{\mathrm{x}} \mathrm{Zn}_{1-\mathrm{x}}(\mathrm{bpp})_{2}\right](\mathrm{NCSe})_{2}$. Dalton Trans. 2014, 43, 7820-7829.

(66) Halcrow, M. A.; Chastanet, G. Spin-crossover and the LIESST effect in $\left[\mathrm{Fe}_{\mathrm{x}} \mathrm{Co}_{1-\mathrm{x}}(\mathrm{bpp})_{2}\right][\mathrm{BF} 4]_{2}(1.00 \leq x \leq 0.77)$. Comparison with bifunctional solid solutions of iron and cobalt spin-crossover centers. Polyhedron 2017, 136, 5-12.

(67) Sylla, M. S.; Baldé, C.; Daro, N.; Desplanches, C.; Marchivie, M.; Chastanet, G. On the Effect of the Internal Pressure on the Photoinduced Spin-Crossover Behavior of $\left[\mathrm{Fe}_{\mathrm{x}} \mathrm{M}_{1-} \mathrm{x}(1,10\right.$-phenanthroline $\left.)_{2}(\mathrm{NCS})_{2}\right]$ Solid Solutions $\left(\mathrm{M}=\mathrm{Ni}^{\mathrm{iI}}, \mathrm{Zn}^{\mathrm{II}}\right.$, and $\left.\mathrm{Cd}^{\mathrm{II}}\right)$. Eur. J. Inorg. Chem. 2018, 2018, 297-304.

(68) Tumanov, S. V.; Veber, S. L.; Greatorex, S.; Halcrow, M. A.; Fedin, M. V. Interplay between Dopant Species and a Spin-Crossover Host Lattice during Light-Induced Excited-Spin-State Trapping Probed by Electron Paramagnetic Resonance Spectroscopy. Inorg. Chem. 2018, 57, 8709-8713.

(69) Docherty, R.; Tuna, F.; Kilner, C. A.; McInnes, E. J. L.; Halcrow, M. A. Suppression of the Jahn-Teller distortion in a sixcoordinate copper(II) complex by doping it into a host lattice. Chem. Commun. 2012, 48, 4055-4057.

(70) Chastanet, G.; Tovee, C. A.; Hyett, G.; Halcrow, M. A.; Létard, J.-F. Photomagnetic studies on spin-crossover solid solutions containing two different metal complexes, $\left[\mathrm{Fe}(1-\mathrm{bpp})_{2}\right]_{\mathrm{x}}[\mathrm{M}-$ (terpy $\left.)_{2}\right]_{1-\mathrm{x}}\left[\mathrm{BF}_{4}\right]_{2}(\mathrm{M}=\mathrm{Ru}$ or Co $)$. Dalton Trans. 2012, 41, 48964902.

(71) Kröber, J.; Codjovi, E.; Kahn, O.; Grolière, F.; Jay, C. A spin transition system with a thermal hysteresis at room temperature. $J$. Am. Chem. Soc. 1993, 115, 9810-9811.

(72) Kahn, O.; Sommier, L.; Codjovi, E. Spin transition Molecular Alloys: An Attempt of Fine Tuning of the Transition Temperatures. Chem. Mater. 2003, 9, 3199-3205.

(73) Calvo Galve, N.; Coronado, E.; Giménez-Marqués, M.; Mínguez Espallargas, G. A Mixed-Ligand Approach for SpinCrossover Modulation in a Linear Fe $\mathrm{F}^{\mathrm{II}}$ Coordination Polymer. Inorg. Chem. 2014, 53, 4482-4490.

(74) Bartual-Murgui, C.; Vela, S.; Darawsheh, M.; Diego, R.; Teat, S. J.; Roubeau, O.; Aromí, G. A probe of steric ligand substituent effects on the spin crossover of $\mathrm{Fe}(\mathrm{II})$ complexes. Inorg. Chem. Front. 2017, 4, 1374.

(75) Sheldrick, G. M. SAINT and SADABS; Bruker AXS Inc.: Madison, WI, USA, 2012.

(76) Sheldrick, G. SHELXT - Integrated space-group and crystalstructure determination. Acta Crystallogr., Sect. A: Found. Adv. 2015, $71,3-8$.

(77) Sheldrick, G. Crystal structure refinement with SHELXL. Acta Crystallogr., Sect. C: Struct. Chem. 2015, 71, 3-8.

(78) Slichter, C. P.; Drickamer, H. G. Pressure-Induced Electronic Changes in Compounds of Iron. J. Chem. Phys. 1972, 56, 2142-2160.

(79) Sorai, M.; Seki, S. Phonon coupled cooperative low-spin ${ }^{1} A_{1}$ high-spin ${ }^{5} \mathrm{~T}_{2}$ transition in $\left[\mathrm{Fe}(\text { phen })_{2}(\mathrm{NCS})_{2}\right]$ and $[\mathrm{Fe}-$ (phen $\left.)_{2}(\mathrm{NCSe})_{2}\right]$ crystals. J. Phys. Chem. Solids 1974, 35, 555-570.

(80) Sorai, M. Heat Capacity Studies of Spin-Crossover Complexes. Top. Curr. Chem. 2004, 235, 153-170.

(81) Sorai, M.; Nakazawa, Y.; Nakano, M.; Miyazaki, Y. Update 1 of: Calorimetric Investigation of Phase Transitions Occurring in Molecule-Based Magnets. Chem. Rev. 2013, 113, PR41-PR122.

(82) Phonsri, W.; Lewis, B. A. I.; Jameson, G. N. L.; Murray, K. S. Double spin crossovers: a new double salt strategy to improve magnetic and memory properties. Chem. Commun. 2019, 55, 1403114034. 